\title{
Supply chain risk management: A literature review
}

\author{
William $\mathrm{Ho}^{1}$, Tian Zheng ${ }^{2}$, Hakan Yildiz ${ }^{3}$ and Srinivas Talluri ${ }^{3, *}$ \\ ${ }^{1}$ Department of Management and Marketing \\ The University of Melbourne \\ 198 Berkeley Street, Carlton \\ Victoria 3010, Australia \\ ${ }^{2}$ Solution Department \\ China Merchants Loscam (Shenzhen) Investment Holding Co., Ltd \\ Room 701-705, Block 3, Fantasia MIC Plaza, 8 Xing Gong Road, Shekou \\ Shenzhen, China \\ ${ }^{3}$ Department of Supply Chain Management \\ Eli Broad Graduate School of Management \\ N370 Business Complex, Michigan State University \\ East Lansing, MI 48824, United States
}

\begin{abstract}
Risk management plays a vital role in effectively operating supply chains in the presence of a variety of uncertainties. Over the years, many researchers have focused on supply chain risk management (SCRM) by contributing in the areas of defining, operationalizing, and mitigating risks. In this paper, we review and synthesize the extant literature in SCRM in the past decade in a comprehensive manner. The purpose of this paper is three-fold. First, we present and categorize SCRM research appearing between 2003 and 2013. Second, we undertake a detailed review associated with research developments in supply chain risk definitions, risk types, risk factors, and risk management/mitigation strategies. Third, we analyze the SCRM literature in exploring potential gaps.
\end{abstract}

Keywords: Supply chain risk management; risk types; risk factors; risk management methods; literature review

*Corresponding author (E-mail: talluri@broad.msu.edu) 


\section{Introduction}

In recent years, supply chain disruptions have impacted the performance of companies. The case of Ericsson is well known in this domain. Due to a fire at a Phillips semiconductor plant in 2000, the production was disrupted, which eventually led to Ericsson's \$400 million loss (Chopra and Sodhi, 2004). The earthquake, tsunami, and the subsequent nuclear crisis that occurred in Japan in 2011 caused Toyota's production to drop by 40,000 vehicles, costing $\$ 72$ million in profits per day (Pettit et al., 2013). The catastrophic Thailand flooding of October 2011 affected the supply chains of computer manufacturers dependent on hard disks, and also disrupted the supply chains of Japanese automotive companies with plants in Thailand (Chopra and Sodhi, 2014). In order to control and mitigate the negative effects caused by such risks, a significant amount of work in the area of supply chain risk management (SCRM) is undertaken in both academia and practitioner circles.

In the last decade, five journal articles reviewing the literature in SCRM have been published. Tang (2006a) reviewed more than 200 journal articles that applied quantitative models that are published between 1964 and 2005. He classified the articles into four categories, i.e., supply management, demand management, product management, and information management for managing supply chain risks. Rao and Goldsby (2009) reviewed 55 journal articles published between 1998 and 2008, and synthesized the diverse literature into a typology of risk factors, including environmental, industrial, organizational, problemspecific, and decision-maker related factors. Tang and Musa (2011) adopted the literature citation analysis on 138 journal articles published between 1995 and first half of 2008, and identified and classified potential risks associated with material flow, financial flow, and information flow. Colicchia and Strozzi (2012) also applied the citation network analysis on 55 journal articles published between 1994 and 2010, and identified the evolutionary patterns and emerging trends in SCRM. Sodhi et al. (2012) reviewed 31 journal articles published between 1998 and 2010 to formulate their own perception of diversity in SCRM. They also conducted open-ended surveys with two focus groups of supply chain researchers, and subsequently a close-ended survey with more than 200 supply chain researchers to present three gaps in SCRM: definition gap (lack of clear consensus on the definition of SCRM), process gap (inadequate coverage of responses to risk incidents), and methodology gap (insufficient use of empirical methods).

Although the aforementioned review articles make significant contributions to SCRM, there are three significant knowledge gaps that motivate us to carry out this study. First, each of these review articles focuses on a particular topic of SCRM as summarized in Table 1, such as risk classification (Tang and Musa, 2011), risk factor analysis (Rao and Goldsby, 2009), risk management methods (Tang, 2006a), or research gap identification (Colicchia and Strozzi, 2012). None of these review articles cover all the SCRM topics. As illustrated in Table 1, the articles published between 2003 and 2013 applying qualitative risk management methods were never reviewed. Besides, certain topics in particular years were also not 
covered as represented by the shaded cells in Table 1. In addition, none of these review articles are recent enough to cover many new studies published after 2010. More specifically, 170 out of 224 journal articles reviewed in this paper were not studied in extant review articles, including 93 journal articles published after 2010 plus 77 journal articles published between 2003 and 2010. Finally, all but two of these papers reviewed only a relatively small number of articles. More specifically, Sodhi et al. (2012) reviewed 31 articles, and Rao and Goldsby (2009) and Colicchia and Strozzi (2012) reviewed 55 articles given the focal area of interest. In order to fill these gaps, this paper presents a comprehensive review of all relevant journal articles in the area of SCRM appearing between 2003 and 2013, and undertakes an effective classification scheme. Our work also proposes a new definition for SCRM by classifying supply chain risk types, risk factors, and risk management methods. Finally, we analyze the literature in exploring potential gaps contributing towards risk management in supply chains.

The remainder of this paper is organized as follows. Section 2 provides an introduction to the research methodology and develops a conceptual framework for classifying the supply chain risks. Section 3 summarizes the existing definitions of supply chain risks and SCRM, and proposes new definitions. Sections 4, 5, and 6 present supply chain risk types, risk factors, and risk management methods, respectively. Section 7 discusses the research analyses and observations. Section 8 identifies gaps in the area of SCRM and recommends future research directions, and finally, section 9 concludes the paper.

\section{Research methodology}

There is a continuous growth in the number of articles focusing on SCRM in the past few years as seen in Figure 1. In view of this, we reviewed the journal articles published between 2003 and 2013. The research methodology, as illustrated in Figure 2, is as follows. First, the search terms were defined. The keywords used in the search process were "supply chain" and "risk". Second, various academic databases were utilized to identify the journal articles including EBSCOhost, Emerald, IEEExplore, Ingenta, Metapress, ProQuest, ScienceDirect, Springer, Taylor and Francis, and Wiley. To achieve the highest level of relevance, only peerreviewed articles written in English and published in International Journals were selected, whereas conference papers, master and doctoral dissertations, textbooks, book chapters, and notes were excluded in this review. As opposed to Tang and Musa (2011), we have not imposed a restriction on the list of journals to ensure that we capture every relevant study regardless of the journal it was published in. Third, several criteria were determined and used to filter the articles. With respect to the criteria, abstracts of articles were examined to check if they cover one or more of the SCRM topics, including supply chain risk types, risk factors, risk management methods, and research gaps identification. The articles were excluded if they do not meet one of these filtration criteria. Fourth, the reference lists of the shortlisted

articles were also carefully evaluated to ensure that there were no other articles of relevance which were omitted in the search. Finally, the content of each article was thoroughly 
reviewed to ensure that the article fits into the context of SCRM and studies at least one of the SCRM topics. This analysis resulted in 224 journal articles.

In order to classify and analyze these articles, we develop a conceptual framework of supply chain risks as shown in Figure 3. In synthesizing various points of views from the literature, we discover that supply chain risks can be divided into two categories - macro risks and micro risks (referred as catastrophic and operational by Sodhi et al. (2012); disruption and operational by Tang (2006a)). Macro risks refer to adverse and relatively rare external events or situations which might have negative impact on companies. Macro risks consist of natural risks (e.g., earthquakes, weather related disasters) and man-made risks (e.g., war and terrorism, and political instability). On the other hand, micro risks refer to relatively recurrent events originated directly from internal activities of companies and/or relationships within partners in the entire supply chain. Generally, macro risks have much greater negative impact on companies in relation to micro risks. Furthermore, micro risks can be divided into four sub-categories: demand risk, manufacturing risk, supply risk, and infrastructural risk. Manufacturing risk refers to adverse events or situations within the firms that affect their internal ability to produce goods and services, quality and timeliness of production, and profitability (Wu et al., 2006). Demand and supply risks refer to adverse events at the downstream and upstream partners of a firm, respectively (Zsidisin, 2003; Wagner and Bode, 2008). In order to ensure the healthy functioning of a supply chain, information technology (Chopra and Sodhi, 2004), transportation (Wu et al., 2006), and financial systems (Chopra and Sodhi, 2004; Wu et al., 2006), are also of critical importance. Any disruptions in these systems can also lead to serious problems in a supply chain. Therefore, we classify the risks relating to these three systems as infrastructural risk.

\section{Definitions}

There is no consensus on the definition of "supply chain risk" and "supply chain risk management" (Sodhi et al., 2012; Diehl and Spinler, 2013). Without a common understanding and clear definition, researchers would find it difficult to communicate with practitioners and gain access to industry to carry empirical studies. Moreover, a consistent definition helps researchers identify and measure the likelihood and impact of the entire set of supply chain risks, and evaluate the effectiveness of supply chain risk management methodologies. Therefore, it is imperative to obtain a clear definition of these terms (Sodhi et al., 2012; Diehl and Spinler, 2013). Sections 3.1 and 3.2 summarize the existing definitions of supply chain risk and SCRM and also propose new definitions.

\subsection{Supply chain risk}

Several researchers provided different definitions for supply risk (Zsidisin, 2003; Ellis et al., 2010), and supply chain risk (Jüttner et al., 2003; Wagner and Bode, 2006; Bogataj and Bogataj, 2007) as summarized in Table 2. Although these definitions have applicability in specific domains, such as supply risk (Zsidisin, 2003; Ellis et al., 2010), information flow 
risk, material flow risk, and product flow risk (Jüttner et al., 2003), they focus on a specific function or a part of a supply chain, and do not span across the entire chain. Given this, and according to the conceptual framework in Figure 3, we define supply chain risk as: "the likelihood and impact of unexpected macro and/or micro level events or conditions that adversely influence any part of a supply chain leading to operational, tactical, or strategic level failures or irregularities”.

\subsection{Supply chain risk management}

Several researchers provided definitions for SCRM, which are summarized in Table 3. While all these definitions have emphasized collaboration with supply chain partners, some of the limitations are related to their focus on specific elements of SCRM and their lack of spanning the SCRM processes in their entirety, type of SCRM methods, and types of events. Given this, and based on the conceptual framework in Figure 3, we define SCRM as: "an interorganizational collaborative endeavour utilizing quantitative and qualitative risk management methodologies to identify, evaluate, mitigate, and monitor unexpected macro and micro level events or conditions, which might adversely impact any part of a supply chain”.

\section{Supply chain risk types}

Among the 224 reviewed journal articles, 20 articles discussed supply chain risk types as presented in Table 4. Eleven of these articles simply identified the risk types without classification (Harland et al., 2003; Cavinato, 2004; Chopra and Sodhi, 2004; Bogataj and Bogataj, 2007; Blackhurst et al., 2008; Manuj and Mentzer, 2008; Tang and Tomlin, 2008; Wagner and Bode, 2008; Tang and Musa, 2011; Tummala and Schoenherr, 2011; Samvedi et al., 2013). Six of these articles classified the risk types into two categories, such as internal and external (Wu, 2006; Trkman and McCormack, 2009; Kumar et al., 2010; Olson and Wu, 2010), or operational and disruption (Tang, 2006a; Ravindran et al., 2010). In addition, three of these articles divided supply chain risk types into three categories with a similar idea but used different terms (Jüttner et al., 2003; Christopher and Peck, 2004; Lin and Zhou, 2011). The three categories are organizational risk or internal risk (e.g., process and control risks), network-related risk or risk within the supply chain (e.g., demand and supply risks), and environmental risk or risk in the external environment (e.g., natural disasters, war and terrorism, and political instability).

Among the 20 articles discussed above, only two articles classified the supply chain risk types according to the degree of the negative impact on companies (Tang, 2006a; Ravindran et al., 2010). Note that macro risks, discussed in Section 2, are akin to disruption risks (Tang, 2006a) and Value-at-risk (VaR) (Ravindran et al., 2010), whereas micro risks are similar to operational risks (Tang, 2006a) and Miss-the-target (MtT) (Ravindran et al., 2010). Besides, some micro risks (demand, manufacturing, and supply risks) have been extensively proposed and studied. Comparatively, other risks (information, transportation, and financial risks) have been paid much less attention. Most importantly, our conceptual framework for 
the supply chain risk classification, illustrated in Figure 3, is believed to be unique and more comprehensive given that it considers a holistic set of risk types with various degrees of impact (macro and micro risks), in both external and internal supply chain (demand, manufacturing, and supply risks), and different types of flow (information, transportation, and financial risks). This holistic risk classification has not been proposed by the previous studies.

\section{Supply chain risk factors}

Among the 224 reviewed journal articles, 14 articles discussed supply chain risk factors. Risk factors are various events and situations that drive a specific risk type. The first group of scholars (8 out of 14 articles) identified risk factors of multiple risk types (Chopra and Sodhi, 2004; Cucchiella and Gastaldi, 2006; Wu et al., 2006; Manuj and Mentzer, 2008; Tuncel and Alpan, 2010; Wagner and Neshat, 2010; Tummala and Schoenherr, 2011; Samvedi et al., 2013). For example, Chopra and Sodhi (2004) explored several risk factors, as shown in Table 5, for various risk types as shown in Table 4. The second group of scholars (3 out of 14 articles) explored factors of specific risk types. For example, Zsidisin and Ellram (2003) considered five supply risk factors. Kull and Talluri (2008) also focused on supply risk, and considered somewhat similar factors. Tsai (2008) focused on time related factors imposing significant influences on the cash flow risk. The last group of scholars (3 out of 14 articles) merely showed a list of potential risk factors without classification (Gaudenzi and Borghesi, 2006; Schoenherr et al., 2008; Hahn and Kuhn, 2012a).

Majority of the risk factors discussed in these 14 articles can be classified into five categories according to our conceptual framework, as shown in Table 5, including macro, demand, manufacturing, supply, and infrastructural (information, transportation, and financial) factors. First, we found that some of the identified risk factors are vague, and it's more appropriate to consider them as risk types rather than risk factors, e.g., risks affecting suppliers, risks affecting customers (Manuj and Mentzer, 2008); demand risk, logistics risk, supplier risk, transportation risk (Schoenherr et al., 2008). We excluded such risk factors in Table 5, and only included the relevant factors. Second, consistent with the findings in Section 4, demand, manufacturing, and supply risks have attracted the most attention. There exists an abundant set of factors, which would give rise to demand, manufacturing, and supply risks. Comparatively, there are less factors suggested for macro, information, transportation, and financial risks. Third, according to our definition of supply chain risk in Section 3.1, different supply chain risk types would have different levels of negative impact and would lead to operational, tactical, or strategic level failures. Similarly, different risk factors within the same risk type would also have different levels of negative impact. Nevertheless, these articles simply identified and/or classified the potential risk factors without quantifying and assessing the degrees of negative impact.

Table 5 shows the risk factors proposed by particular authors (i.e., which articles proposed which risk factors). As there are many duplicated factors in Table 5, it is 
synthesized into Table 6 so as to help readers identify factors of particular risk types efficiently, and differentiate between macro and micro risk factors more easily. Note that some of these risk factors are associated with generic risk types, such as inbound supply risk (Wu et al., 2006) while some others are factors of specific risk types, such as cash flow risk (Tsai, 2008). Before incorporating such risk factors listed in Table 6 into a particular supply chain, industrial characteristics and features of supply chain should be taken into account.

\section{SCRM methods}

In the past decade, a number of qualitative and quantitative methods and tools have been developed and applied to manage supply chain risks. Section 6.1 presents the research studying specific or individual SCRM process, such as risk identification, risk assessment, risk mitigation, and risk monitoring. Section 6.2 discusses other research focusing on more than one process or integrated management. Note that some sections are relatively lengthy because those areas have attracted more attention, whereas some other sections are relatively concise, which means that they have been under-researched. The following sub-sections help in understanding whether individual or integrated management process has attracted more attention, and which SCRM process has been the most prevalently studied.

\subsection{Individual SCRM process}

\subsubsection{Risk identification}

Risk identification is the first step in the SCRM process. It involves the identification of risk types, factors, or both. The first group of researchers developed qualitative or quantitative methods for identifying potential supply chain risks, such as the analytic hierarchy process (AHP) method (Tsai et al., 2008), a supply chain vulnerability map (Blos et al., 2009), and a conceptual model (Trkman and McCormack, 2009). Another group of researchers focused on risk factor identification using the AHP (Gaudenzi and Borghesi, 2006) and the hazard and operability analysis method (Adhitya et al., 2009). Some other scholars proposed qualitative tools to identify both risk types and risk factors, such as a qualitative value-focused process engineering methodology (Neiger et al., 2009) and a supply chain risk identification system, based on knowledge-based system approach (Kayis and Karningsih, 2012).

Most of the above articles applied qualitative methods for risk identification (Adhitya et al., 2009; Blos et al., 2009; Neiger et al., 2009; Trkman and McCormack, 2009; Kayis and Karningsih, 2012). They did not prioritize nor quantify the negative impact of neither risk types nor risk factors.

\subsubsection{Risk assessment}

Risk assessment is associated with the probability of an event occurring and the significance of the consequences (Harland et al., 2003). In the past decade, a number of risk assessment methods have emerged, especially for supply risk assessment. Owing to the abundant 
published articles in this area, we classify them according to the risk types studied in the conceptual framework, including macro and micro risk assessments.

\subsubsection{Macro risk assessment}

Ji and Zhu (2012) evaluated the salvable degrees of the affected areas in a destructive earthquake by the extension technique. They developed a bi-objective optimization model with the urgent relief demand time-varying fill rate maximization and distribution timevarying window minimization to distribute supplies to the identified affected area sets. The methodology was illustrated with a hypothetical numerical example.

\subsubsection{Demand risk assessment}

A number of researchers analyzed the impact of demand volatility on inventory management (Ballou and Burnetas, 2003; Cachon, 2004; Talluri et al., 2004; Betts and Johnston, 2005; Sodhi, 2005; Xiao and Yang, 2008; Radke and Tseng, 2012). Some of them provided useful insights on safety stock reduction. Ballou and Burnetas (2003) compared a traditional inventory planning approach with one that is based on filling customer demand from any one of several stocking locations, referred to as cross filling, while considering the dispersion of demand among stocking locations. It was revealed that cross filling can help reducing safety stocks. Talluri et al. (2004) developed a safety stock model and benchmarked it with existing models for managing make-to-stock inventories under demand and supply variations. Based on a case study at an over-the-counter pharmaceutical company, the proposed safety stock model performed well in terms of cost savings. Betts and Johnston (2005) presented the multi-item constrained inventory model to compare just-in-time (JIT) replenishment with component substitution under stochastic demand. The analysis showed that JIT replenishment is more effective than component substitution because of less investment in safety stock.

Some other scholars analyzed the impact of demand visibility and bullwhip effect on supply chain performance. Smaros et al. (2003) used a discrete-event simulation model to show that a partial improvement of demand visibility can improve production and inventory control efficiency. Reiner and Fichtinger (2009) developed a dynamic model to evaluate supply chain process improvements under consideration of different forecast methods. They pointed out that dampening of the order variability decreases the bullwhip effect and the average on-hand inventory but with the problem of a decreasing service level. Sucky (2009) suggested that the variability of orders increases as they move up the supply chain from retailers to wholesalers to manufacturers to suppliers. He concluded that the bullwhip effect is overestimated if a simple supply chain is assumed and risk pooling effects are present.

A common limitation of the above articles is that most of the proposed methods were not implemented in real industrial cases (Ballou and Burnetas, 2003; Smaros et al., 2003; Cachon, 2004, Betts and Johnston, 2005; Sodhi, 2005; Xiao and Yang, 2008; Reiner and Fichtinger, 2009; Sucky, 2009; Radke and Tseng, 2012). Lack of actual implementation and 
verification would make the potential users doubtful about the effectiveness and efficiency of the proposed methods. Besides, several of the above articles simplified the studied problems with stylized supply chains (Ballou and Burnetas, 2003; Smaros et al., 2003; Cachon, 2004).

\subsubsection{Manufacturing risk assessment}

There exist three research studies on manufacturing risk assessment. They applied different methods to assess different manufacturing risks in different supply chains. Cigolini and Rossi (2010) proposed the fault tree approach to analyze and assess the operational risk at the drilling, primary transport, and refining stages of an oil supply chain. They concluded that different stages are affected by various operational risks according to the differences in plants. Therefore, each plant should be provided with a specifically conceived risk management process. Dietrich and Cudney (2011) applied a Pugh method adaption to assess risk coupled with manufacturing readiness level for emerging technologies in a global aerospace supply chain. They revealed that executive management can evaluate the entire emerging technology portfolio more effectively with the proposed methodology. Tse and Tan (2011) constructed a product quality risk and visibility assessment framework using the margin incremental analysis for a toy manufacturing company. They argued that better visibility of risk in supply tiers could minimize the quality risk.

There exist limitations in the above articles. Cigolini and Rossi (2010) only focused on three stages of an oil supply chain, while ignoring operational risk assessment at some other crucial stages (e.g., design, construction, and outsourcing). The risk assessment matrix proposed by Dietrich and Cudney (2011) is fairly simplistic as it is based on only three levels (i.e., “green”, “yellow”, and “red”). Tse and Tan (2011) neither quantified risks and their factors, nor proposed any mitigating actions for the identified manufacturing risk.

\subsubsection{Supply risk assessment}

Supply risk assessment has attracted much attention. Most of the articles studied the supplier evaluation and selection problem while considering a variety of supply risks, such as poor quality (Talluri and Narasimhan, 2003; Talluri et al., 2006), late delivery (Talluri and Narasimhan, 2003; Talluri et al., 2006), uncertain capacity (Kumar et al., 2006; Viswanadham and Samvedi, 2013), dispersed geographical location (Chan and Kumar, 2007), supplier failure (Kull and Talluri, 2008; Ravindran et al., 2010; Ruiz-Torres et al., 2013), supplier's financial stress (Lockamy III and McCormack, 2010), supply disruption (Wu and Olson, 2010; Meena et al., 2011), poor supplier service (Wu et al., 2010; Chen and Wu, 2013), suppliers' risk management ability and experience (Ho et al., 2011), and lack of supplier involvement (Chaudhuri et al., 2013). A wide range of quantitative methods have been proposed to deal with this problem, including mathematical programming and data envelopment analysis (DEA) approaches (Talluri and Narasimhan, 2003; Kumar et al., 2006; Talluri et al., 2006; Ravindran et al., 2010; Wu and Olson, 2010; Wu et al., 2010; Meena et al., 2011), multi-criteria decision making and AHP approaches (Chan and Kumar, 2007; 
Blackhurst et al., 2008; Kull and Talluri, 2008; Ho et al., 2011; Chen and Wu, 2013; Viswanadham and Samvedi, 2013), Bayesian networks (Lockamy III and McCormack, 2010), decision tree approach (Ruiz-Torres et al., 2013), and fuzzy based failure mode and effect analysis (FMEA) with ordered weighted averaging approach (Chaudhuri et al., 2013).

In addition to the above supply risks, some other supply risks have also been analyzed and assessed, such as second-tier supply failure (Kull and Closs, 2008), offshore sourcing risk (Schoenherr et al., 2008), unreliable dual sourcing network (Iakovou et al., 2010), supplier non-conformance risk (Wiengarten et al., 2013), supplier incapability (Johnson et al., 2013), and supplier unreliability (Cheong and Song, 2013).

Different from the above approaches focusing on the assessment of supply risks, the following articles studied supply risk assessment methods and models. Zsidisin et al. (2004) examined tools and techniques that purchasing organizations implement for assessing supply risk within an agency theory context. They indicated that purchasing organizations can assess supply risk with techniques that focus on addressing supplier quality issues, improving supplier processes, and reducing the likelihood of supply disruptions. Ellegaard (2008) applied a case based methodology to analyze the supply risk management practices of 11 small company owners (SCOs). They confirmed that the 11 studied SCOs applied almost the same supply risk management practices, which can be characterized as defensive. Wu and Olson (2008) used simulated data to compare three types of risk evaluation models: chanceconstrained programming, DEA, and multi-objective programming models. Results from three models are consistent with each other in selecting preferred suppliers. Azadeh and Alem (2010) benchmarked three types of supplier selection models under certainty, uncertainty and probabilistic conditions, including DEA, Fuzzy DEA, and chance-constrained DEA. Results from three models are also consistent with each other with respect to the worst suppliers.

Supplier evaluation and selection has attracted the most attention is this category. Many of these articles focused on conceptual model development and demonstration using simulated data (Chan and Kumar, 2007; Ravindran et al., 2010; Wu and Olson, 2010; Wu et al., 2010; Meena et al., 2011; Viswanadham and Samvedi, 2013; Ruiz-Torres et al., 2013). Thus, the use of real data to test the efficacy of these methods is still missing. Moreover, some of these articles have other technical limitations. For example, Talluri and Narasimhan (2003) and Talluri et al. (2006) only utilized a single input measure in the DEA analyses. Kull and Talluri (2008) assumed current supplier capabilities will remain unchanged into the future. Lockamy III and McCormack (2010) assumed that all suppliers are willing to share their accurate and reliable risk profile data with their customers. Ruiz-Torres et al. (2013) assumed all the input parameters and supplier characteristics to be deterministic.

\subsubsection{Financial risk assessment}

There are four research studies on financial risk assessment. Two of them focused on specific financial risks. Tsai (2008) modelled the supply chain related cash flow risks by the standard 
deviations of cash inflows, outflows, and net flows of each period in a planning horizon. They recommended the best policy of using asset-backed securities to finance accounts receivable as a means to shorten the cash conversion cycle and lower the cash inflow risk. Liu and Nagurney (2011) developed a variational inequality model to study the impact of foreign exchange risk and competition intensity on supply chain companies that are involved in offshore-outsourcing activities. Their simulation results indicated that in general the riskaverse firm has lower profitability and lower risk than the risk-neutral firm.

On the other hand, two of the studies focused on generic financial risk. Franca et al. (2010) formulated a multi-objective programming model with the Six Sigma concepts to evaluate financial risk. They showed that the financial risk decreases as the sigma level increases. Liu and Cruz (2012) studied the impact of corporate financial risk and economic uncertainty on the values, profits, and decisions of supply chains. They found that suppliers are willing to sacrifice some profit margins to gain more businesses from manufacturers with lower financial risk and with lower sensitivity to economic uncertainty. A common drawback with these approaches is that they focused on simulated data instead of using real case data.

\subsubsection{Information risk assessment}

Durowoju et al. (2012) used discrete-event simulation to investigate the impact of disruption in the flow of critical information needed in manufacturing operations on collaborating members. They revealed that the retailer experiences the most uncertainty in the supply chain while the holding cost constitutes the most unpredictable cost measure when a system failure breach occurs. In their study, a generic information technology risk was studied, and no risk factors were identified nor quantified.

\subsubsection{General risk assessment}

Articles that do not assess specific risk types are described in this section. The topics of these articles are diversified, and there are four major categories. First, a number of researchers attempted to evaluate, assess, and quantify generic supply chain risks. Brun et al. (2006) developed a so-called supply network opportunity assessment package methodology to evaluate advanced planning and scheduling and supply chain management implementation projects with risk analysis. Bogataj and Bogataj (2007) used parametric linear programming model to measure the costs of risk based on the net present value of activities. Wu et al. (2007) proposed a disruption analysis network approach to determine how changes or disruptions propagate in supply chains and calculated their impact on the supply chain system. Kumar et al. (2010) applied the artificial bee colony technique, genetic algorithms, and particle swarm optimization to identify operational risk factors, their expected value and probability of occurrence, and associated additional cost. Khilwani et al. (2011) proposed the hybrid Petri-net approach for modelling, performance evaluation, and risk assessment of a supply chain. Olson and Wu (2011) used DEA and the Monte-Carlo simulation to identify various risk performance measures for outsourcing and compared expected performance of 
vendors under risk and uncertainty in a supply chain. Wang et al. (2012) applied fuzzy AHP to assess risk of implementing various green initiatives in the fashion industry. Samvedi et al. (2013) applied fuzzy AHP and fuzzy TOPSIS approaches to quantify the risks in a supply chain, and aggregated the values into a comprehensive risk index.

The second category is concerned with the assessment of relationship between supply chain risks and strategies. Craighead et al. (2007) suggested that the best practices in purchasing, including supply base reduction, global sourcing, and sourcing from supply clusters might have negative impact on the severity of supply chain disruptions. Laeequddin et al. (2009) suggested that the supply chain members should strive to reduce the membership risk levels to build trust rather than striving to build trust to reduce the risk. Tomlin (2009) found that contingent sourcing is preferred to supplier diversification as the supply risk increases, while diversification is preferred to contingent sourcing as the demand risk increases. Hult et al. (2010) studied supply chain investment decisions when facing high levels of risk uncertainty. They extended real options theory to the supply chain context by examining how different types of options are approached relative to supply chain project investments. Wang et al. (2011) applied the unconstrained and constrained mathematical programming models to assess the relationship between various supply chain strategies and the regulatory trade risk. They established that the direct and split strategy profits increase in the non-tariff barriers price variance but decrease in the mean price.

Third, Jüttner and Maklan (2011) and Pettit et al. (2013) both evaluated the supply chain resilience. Jüttner and Maklan (2011) revealed that knowledge management seems to enhance the supply chain resilience by improving flexibility, visibility, velocity, and collaboration capabilities of the supply chain. Pettit et al. (2013) suggested a correlation between increased resilience and improved supply chain performance.

Fourth, Wagner and Neshat (2010) and Berle et al. (2013) both assessed supply chain vulnerability. Wagner and Neshat (2010) concluded that if supply chain managers were more capable of measuring and managing supply chain vulnerability, they could reduce the number of disruptions and their impact. Berle et al. (2013) argued identifying the "vulnerability inducing bottlenecks" of transportation systems allows for realizing more robust versions of these systems in a cost-effective manner.

While to above mentioned methods addressed a variety of issues, they are not devoid of limitations. Brun et al. (2006) considered the deterministic characteristics of projects in their risk analysis. Kumar et al. (2010) focused on a single-product supply chain network. Wagner and Neshat (2010) claimed that the applicability of their proposed approach heavily depends on the availability of data that quantifies the factors of supply chain vulnerability. Khilwani et al. (2011) indicated that the proposed method is incapable of modelling the changes performed in the network during the risk management process. Wang et al. (2012) pointed out that the functionality of their model is heavily dependent on the knowledge, expertise, and communication skills of assessors. Berle et al. (2013) studied a simplified version of a 
real transportation system. Samvedi et al. (2013) emphasized that their risk index is simply generic rather than industry-specific.

\subsubsection{Risk mitigation}

In this section, we classify risk mitigation methods in a similar manner as the risk assessment methods are discussed in Section 6.1.2.

\subsubsection{Macro risk mitigation}

Hale and Moberg (2005) used a five-stage disaster management framework for secure site location selection. The framework consists of planning, mitigation, detection, response, and recovery. However, the proposed set covering location model minimizes the number of secure site locations rather than the level of risk exposure. In order to help firms succeed before, during, and after a major disruption, Tang (2006b) presented nine strategies to manage the inherent fluctuations efficiently and make the supply chains more resilient. The strategies are postponement, strategic stock, flexible supply base, make-and-buy, economic supply incentives, flexible transportation, revenue management, dynamic assortment planning, and silent product rollover. However, the proposed mitigation strategies were not assessed and benchmarked to see which are more effective and efficient.

\subsubsection{Demand risk mitigation}

Significant number of researches focused on demand risk mitigation and supply chain decision making under stochastic demand. The first group of researchers determined the optimal order placement and replenishment plan in order to minimize the impact of demand uncertainty. Various methodologies have been developed and applied, including automatic pipeline inventory and order based production control system algorithm (Towill, 2005), twoperiod financial model (Aggarwal and Ganeshan, 2007), buyer's risk adjustment model (Shin and Benton, 2007), multiple regression model (Hung and Ryu, 2008), simulation model (Schmitt and Singh, 2012), newsvendor model (Arcelus et al., 2012; Tang et al., 2012), and mathematical programming, such as stochastic integer linear programming model (Snyder et al., 2007), mixed-integer stochastic programming model (Lejeune, 2008), stochastic linear programming model (Sodhi and Tang, 2009), and mixed integer nonlinear programming model (Kang and Kim, 2012).

The second group of researchers analyzed the forecasting techniques to minimize demand risk. Guo et al. (2006) constructed a macro prediction market model, which can aggregate information about demand risk to achieve accurate demand forecast sharing in the supply chain. Datta et al. (2007) modified the forecasting technique called Generalized Autoregressive Conditional Heteroskedasticity (GARCH) to model demand volatility and better manage risk. Crnkovic et al. (2008) presented a simulation-based decision-support framework to evaluate and select alternative forecasting methods in uncertain demand 
environments. Sayed et al. (2009) presented an improved genetic algorithm to choose the best weights among the statistical methods and to optimize the forecasted activities combinations that maximize profit, which in turn, balance risk of over-stocking and stockouts.

The third group of researchers proposed the risk sharing contracts to minimize the loss due to uncertain demand. Chen et al. (2006), Xiao and Yang (2009), and Chen and Yano (2010) focused on two-tier supply chains, and proposed risk sharing contracts to minimize the loss of manufacturer (e.g., overproduction) and the loss of retailers (e.g., overstocking) under demand uncertainty (Chen et al., 2006; Xiao and Yang, 2009) or weather sensitive demand (Chen and Yano, 2010). Different from the above, Kim (2013) studied a four-tier supply chain under dynamic market demands, and proposed the bilateral contracts with order quantity flexibility. It was revealed that demand fluctuation can be effectively absorbed by the contract scheme, which enables better inventory management and customer service.

The following articles also focus on demand risk mitigation but do not fall into the aforementioned subcategories. Rao et al. (2005) showed that a firm can optimize expected profits by quoting a uniform guaranteed maximum lead time to all customers under demand uncertainty. Huang et al. (2009) presented a dynamic system model of manufacturing supply chains, which can proactively manage disruptive events and absorb the demand shock. BenTal et al. (2011) applied a multi-period deterministic linear programming to generate a robust logistics plan that can mitigate demand uncertainty in humanitarian relief supply chains.

There are limitations associated with some of the above articles. For example, Rao et al. (2005) assumed the lead time to all customers for all products are the same. Chen et al. (2006) and Guo et al. (2006) assumed that retail prices are exogenously set and are the same for all retailers. Snyder et al. (2007) assumed demand parameters are known with certainty. Shin and Benton (2007) did not consider all inventory variables, such as safety stock, service level, and reorder point. Hung and Ryu (2008) used students as surrogates for the actual purchasing and supply chain managers in a supply chain experiment. Lei et al. (2012) assumed the relationship between demand and price is linear.

\subsubsection{Manufacturing risk mitigation}

The following articles focused on mitigation of various manufacturing risk factors, including quality risk (Kaya and Özer, 2009; Hung, 2011; Sun et al., 2012), lead time uncertainty (Li, 2007), random yield risk (He and Zhang, 2008), nonconforming product design (Khan et al., 2008), capacity inflexibility (Hung, 2011), and machine failures (Kenné et al., 2012). The methods used are longitudinal case study (Khan et al., 2008), newsvendor model (Li, 2007), linear programming model (Kaya and Özer, 2009), stochastic dynamic model (Kenné et al., 2012), P-chart solution model (Sun et al., 2012), unconstrained and constrained mathematical programming models (He and Zhang, 2008), and integrated methodology, combining analytic network process (ANP), fuzzy GP, five forces analysis, and VaR (Hung, 2011). 
There are limitations associated with some of the above articles. Li (2007) and Kenné et al. (2012) considered only one type of products in their models. He and Zhang (2008) and Sun et al. (2012) considered one supplier and one retailer in their analyses. Kaya and Özer (2009) assumed the demand function to be linear.

\subsubsection{Supply risk mitigation}

A significant amount of work is related to supply risk mitigation. Earlier studies in the review period carried out empirical studies, which showed that supply risk can be mitigated by implementing behaviour-based management techniques (Zsidisin and Ellram, 2003), by building strategic supplier relationships (Giunipero and Eltantawy, 2004; Hallikas et al., 2005), through early supplier involvement (Zsidisin and Smith, 2005), by adopting business continuity planning as a formal risk management technique (Zsidisin et al., 2005), and by reducing supply base complexity (Choi and Krause, 2006).

Most of the attention has been confined to the sourcing decisions. First, some scholars determined the optimal number of suppliers in the presence of catastrophic risks (Berger et al., 2004) or supplier failure risks (Ruiz-Torres and Mahmoodi, 2007). It was found that additional suppliers are needed when the disaster loss increases significantly (Berger et al., 2004) or the suppliers become less reliable (Ruiz-Torres and Mahmoodi, 2007). Second, some scholars evaluated single, dual or multiple sourcing strategies. There is a consensus that a dual sourcing strategy outperforms a single sourcing one in the presence of a supply disruption (Yu et al., 2009; Li et al., 2010; Xanthopoulos et al., 2012). However, the benefits of multiple sourcing strategies are not significant. Costantino and Pellegrino (2010) identified the probabilistic benefits of adopting the multiple sourcing strategy in risky environments for a specific case. Fang et al. (2013) demonstrated that the addition of a third or more suppliers brings much less marginal benefits. Third, a number of scholars determined the supplier selection and order allocation to minimize supply risk using quantitative methods, such as fuzzy multi-criteria decision making model (Haleh and Hamidi, 2011), newsvendor model (Giri, 2011), unconstrained and constrained mathematical programming models (Chopra et al., 2007; Gümüş et al., 2012), stochastic linear programming model (Keren, 2009), multistage stochastic programming model (Shi et al., 2011), mixed integer nonlinear programming model (Meena and Sarmah, 2013), stochastic mixed integer programming approach (Sawik, 2013a), mixed integer programming model (Sawik, 2013b), and fuzzy stochastic multiobjective programming model (Wu et al., 2013). It was found that the suppliers with high disruption probability or with high prices are allocated the lowest fractions of the total demand or are not selected at all (Sawik, 2013a). Besides, the cost of supplier has more influence on order allocation than supplier's failure probability (Meena and Sarmah, 2013).

The following articles also focus on supply risk mitigation but do not fall into the aforementioned subcategories, such as evaluation and selection of the optimal disruption management strategy (Tomlin, 2006; Yang et al., 2009; Colicchia et al., 2010; Schmitt, 2011), determination of the optimal inventory level or policies (Schmitt et al., 2010; Glock and Ries, 
2013; Son and Orchard, 2013), investigation of how managers mitigate global sourcing risks (Christopher et al., 2011; Vedel and Ellegaard, 2013), risk and quality control of a supplier (Tapiero, 2007), allocation of supplier development investments among multiple suppliers (Talluri et al., 2010), analysis of the impact of strategic information acquisition and sharing on supply risk mitigation (Wakolbinger and Cruz, 2011), examination of the effectiveness of hybrid push-pull strategy for supply risk mitigation (Kim et al., 2012), and exploration of actions to proactively mitigate supplier insolvency risk (Grötsch et al., 2013).

There are limitations associated with some of the above articles. Berger et al. (2004) assumed that the probability of the unique event that brings down a particular supplier is the same for all suppliers. Zsidisin and Smith (2005) only conducted a single case study. RuizKeren (2009) studied a simple supply chain with two tiers in a single period environment. Yang et al. (2009), Schmitt (2011), Meena and Sarmah (2013), and Son and Orchard (2013) assumed the demand to be deterministic. Yu et al. (2009) assumed the supplier's capacity to be infinite. Talluri et al. (2010) suggested that their model is inappropriate for selecting new candidate suppliers for supplier development. Christopher et al. (2011) only considered the perspectives of the buying firm. Giri (2011) and Xanthopoulos et al. (2012) considered a single period and a single product in their studies. Glock and Ries (2013) focused on homogeneous suppliers, which restricts its applicability to industries with homogeneous mass products. Grötsch et al. (2013) conducted a survey with comparatively small sample size. Sawik (2013a) did not consider the quality of supplied parts. Vedel and Ellegaard (2013) analyzed a limited set of in-depth interviews in one industry.

\subsubsection{Transportation risk mitigation}

There is only one study that we identified that relates to transportation risk mitigation. Hishamuddin et al. (2013) formulated an integer nonlinear programming model to determine the optimal production and ordering quantities for the supplier and retailer, as well as the duration for recovery subject to transportation disruption, which yields the minimum relevant costs of the system. Their results showed that the optimal recovery schedule is highly dependent on the relationship between the backorder cost and the lost sales cost parameters. They studied a simple two-tier supply chain with one supplier and one retailer, and assumed the demand to be deterministic.

\subsubsection{Financial risk mitigation}

Hofmann (2011) discussed the concept of natural hedging in supply chains. They found that natural hedging of currency and commodity price fluctuations can reduce supply chain vulnerability. Raghavan and Mishra (2011) constructed a nonlinear programming model to show that if one of the firms in the supply chain has sufficiently low cash, a joint decision on the loan amount is beneficial for the lender and the borrowing firms than an independent decision. Lundin (2012) applied the network flow modelling to mitigate the financial risks in 
the cash supply chains. Their results showed that centralization from two to one central bank storage facilities led to unintended increases in transportation costs and financial risk.

There are limitations associated with the above articles. Hofmann (2011) used a brief literature review and a conceptual research design in their study. Raghavan and Mishra (2011) considered a simple two-tier supply chain with one manufacturer and one retailer. Lundin (2012) only considered transportation and cash opportunity costs, while neglecting production and warehousing costs.

\subsubsection{Information risk mitigation}

Du et al. (2003) suggested companies to construct attribute correspondence matrices for databases so that they can share data with both upstream and downstream supply chain partners without leaking information to competitors. They only considered the vertical relationships of companies, while neglecting the horizontal relationships of new partners. Le et al. (2013) examined how data sharing has the potential to create risk for enterprises in retail supply chain collaboration, and proposed an association rule hiding algorithm to remove sensitive knowledge from the released database, and minimize the data distortion.

\subsubsection{General risk mitigation}

There exists a broad range of researches focusing on general risk mitigation, and there are two major categories. First, a number of scholars conducted empirical research or developed quantitative methods to investigate the effective ways of minimizing supply chain risks. Their results showed that supply chain risks can be mitigated by increasing flexibility (Tang and Tomlin, 2008; Manuj and Mentzer, 2008; Skipper and Hanna, 2009; Yang and Yang, 2010; Chiu et al., 2011; Talluri et al., 2013), building collaborative relationships among supply chain members (Faisal et al., 2006; Lavastre et al., 2012; Leat and Revoredo-Giha, 2013; He, 2013; Chen et al., 2013), sharing information in the supply chain (Christopher and Lee, 2004; Faisal et al., 2006), managing suppliers (Xia et al., 2011; Wagner and Silveira-Camargos, 2012), adopting co-opetition (Bakshi and Kleindorfer, 2009), increasing agility (Braunscheidel and Suresh, 2009), implementing corporate social responsibility activities (Cruz, 2009; 2013), understanding diverse organization cultures (Dowty and Wallace, 2010), and applying a new pull system called the multi Kanban system for disassembly (Nakashima and Gupta, 2012).

Second, several scholars developed quantitative models or framework to mitigate supply chain risks, such as a so-called super network model that integrates global supply chain networks with social networks (Cruz et al., 2006), the Supply Chain Risk Structure Model and the Supply Chain Risk Dynamics Model (Oehmen et al., 2009), the house of risk that combines the QFD and FMEA (Pujawan and Geraldin, 2009), and a two-stage stochastic integer programming model (Hahn and Kuhn, 2012b). 
There are limitations associated with some of the above articles as well. Cruz et al. (2006) assumed that the manufacturers are involved in the production of a homogeneous product. Manuj and Mentzer (2008) focused on internal stakeholders only. Tang and Tomlin (2006) did not examine the benefits of a combination of different flexibility strategies. Bakshi and Kleindorfer (2009) and Chiu et al. (2011) studied simple supply chains with only one supplier and one retailer. Braunscheidel and Suresh (2009) and Skipper and Hanna (2009) surveyed a limited range of respondents. Xia et al. (2011) assumed exogenous wholesale prices. Lavastre et al. (2012) used simple statistical tools (average and standard deviation). He (2013) used the additive demand function instead of the multiplicative demand model.

\subsubsection{Risk monitoring}

Comparatively, risk monitoring has attracted less attention in the literature. Zhang et al. (2011) developed an integrated abnormality diagnosis model, combining the fuzzy set theory and the radial base function neural network, to provide pre-warning signals of production quality in the food production supply chain. Their simulation results showed that the proposed pre-warning system can effectively identify abnormal data types, and accurately determine whether a warning should be issued. The limitations are that the model was not verified using real data and only quality risk was considered.

\subsection{Integrated SCRM processes}

In addition to the research discussed in Section 6.1, several researchers focused and studied integrated SCRM processes.

\subsubsection{SCRM conceptual frameworks}

A wide variety of qualitative and quantitative based conceptual frameworks have been proposed to deal with more than one process of SCRM. Majority of these studies focused on two SCRM processes, such as risk identification and assessment (Peck, 2005; Smith et al., 2007; Cheng and Kam, 2008; Wagner and Bode, 2008), risk identification and mitigation (Christopher and Peck, 2004; Oke and Gopalakrishnan, 2009), and risk assessment and mitigation (Kleindorfer and Saad, 2005; Blome and Schoenherr, 2011; Giannakis and Louis, 2011; Speier et al., 2011; Hahn and Kuhn, 2012a; Kumar and Havey, 2013).

Kern et al. (2012) found that superior risk identification supports the subsequent risk assessment and this in turn leads to better risk mitigation. As there is a significant relationship between these three SCRM processes, more focus should be confined to three instead of two processes. Some researchers developed conceptual framework for the risk identification, assessment, and mitigation processes (Ritchie and Brindley, 2007; Foerstl et al., 2010; Bandaly et al., 2012; Kern et al., 2012; Ghadge et al., 2013). The five major components in their framework are risk identification, risk assessment, risk consequences, risk management response, and risk performance outcomes. 
A common drawback of the above articles is due to the conceptualization of their frameworks. The frameworks were not verified using real case data or their implementation was not explicitly described. Besides, there are specific limitations related to some of the above articles. Peck (2004), Ritchie and Brindley (2007), Oke and Gopalakrishnan (2009), and Ghadge et al. (2013) all conducted a single case study. Smith et al. (2007) did not measure the consequences of information technology risks. Speier et al. (2011) did not examine the supply chain design initiatives from a cost perspective. Kern et al. (2012) used perceptual data from single informants.

\subsubsection{SCRM procedures or approaches}

Unlike the articles presented in Section 6.2.1 which are conceptual in nature, the following articles proposed detailed procedures or approaches for SCRM. Most of these articles applied qualitative approaches. There are five major steps for SCRM, such as analyze the supply chains (Harland et al., 2003; Cucchiella and Gastaldi, 2006), identify the risk types and factors (Harland et al., 2003; Chopra and Sodhi, 2004; Hallikas et al., 2004; Norrman and Jansson, 2004; Cucchiella and Gastaldi, 2006; Knemeyer et al., 2009; Tummala and Schoenherr, 2011), assess the likelihood of occurrence and overall impact (Harland et al., 2003; Hallikas et al., 2004; Norrman and Jansson, 2004; Cucchiella and Gastaldi, 2006; Knemeyer et al., 2009; Tummala and Schoenherr, 2011), select and implement risk mitigation strategies (Harland et al., 2003; Chopra and Sodhi, 2004; Hallikas et al., 2004; Norrman and Jansson, 2004; Cucchiella and Gastaldi, 2006; Knemeyer et al., 2009; Tummala and Schoenherr, 2011), and continuously improve (Hallikas et al., 2004; Norrman and Jansson, 2004; Tummala and Schoenherr, 2011). Comparatively, risk identification, assessment, and mitigation have attracted the most attention as found in section 6.2.1. More focus should be confined to pre-SCRM (analyze the supply chains) and post-SCRM (continuously improve).

There is relatively less work proposing quantitative approaches for the integrated SCRM. Also, the quantitative approaches only covered two SCRM processes, such as risk identification and assessment (Wu et al., 2006), risk assessment and mitigation (Tuncel and Alpan, 2010), and risk identification and mitigation (Xia and Chen, 2011; Diabat et al., 2012). Nevertheless, these quantitative approaches have their advantages in terms of quantifying the likelihood of occurrence and overall impact of risk factors with AHP (Wu et al., 2006) or the failure mode, effects and criticality analysis technique (Tuncel and Alpan, 2010), and measuring the effectiveness and efficiency of risk mitigation strategies using the Petri-net based simulation (Tuncel and Alpan, 2010), risk identification and mitigation via ANP approach (Xia and Chen, 2011) and interpretive structural modelling (Diabat et al., 2012).

A limitation associated with the qualitative articles is that most of them mainly explain the steps or phases of the SCRM approaches but not demonstrate how the approach can be applied (Chopra and Sodhi, 2004; Hallikas et al., 2004; Cucchiella and Gastaldi, 2006; 
Knemeyer et al., 2009; Tummala and Schoenherr, 2011). Only two of them clearly showed their approaches with the aid of real-life cases. For example, Norrman and Jansson (2004) demonstrated their four-step SCRM approach using the case of Ericsson. Sinha et al. (2004) applied their supply chain operations reference (SCOR) model in the aerospace supply chains. Along the same lines, there are also drawbacks with some of the quantitative articles. $\mathrm{Wu}$ et al. (2006) limited the scope of their model to a single-tier environment. Tuncel and Alpan (2010) focused only on the point of view of the manufacturer. Diabat et al. (2012) stated that their model is highly dependent on the judgements of the expert team.

\subsubsection{Supply chain network design}

A number of articles formulated mathematical programming models for the optimal supply chain network design problem, which consists of location, production, transportation, and inventory decisions. The models identified and mitigated various risk types, such as demand risk (Goh et al., 2007; Poojari et al., 2008; Park et al., 2010; Georgiadis et al., 2011; Qiang and Nagurney, 2012; Baghalian et al., 2013), manufacturing risk (Qiang and Nagurney, 2012; Kumar and Tiwari, 2013), supply risk (Mak and Shen, 2012; Baghalian et al., 2013), and financial risk (Goh et al., 2007; Azaron et al., 2008; Azad and Davoudpour, 2013).

A wide range of mathematical programming models has been developed, including multi-stage stochastic programming model (Goh et al., 2007), multi-objective stochastic programming model (Azaron et al., 2008), two-stage stochastic integer programming model (Poojari et al., 2008), integer nonlinear programming model (Park et al., 2010), mixed integer linear programming model (Georgiadis et al., 2011), stochastic linear programming model (Mak and Shen, 2012), linear programming model (Qiang and Nagurney, 2012), convex mixed integer programming model (Azad and Davoudpour, 2013), stochastic mixed integer nonlinear programming model (Baghalian et al., 2013), and mixed integer nonlinear programming model (Kumar and Tiwari, 2013).

A common drawback is that most of the above articles did not apply their proposed models in real cases but simply used simulated data to prove their effectiveness and efficiency, except Baghalian et al. (2013) who studied a real-life case in the rice industry of a country in the Middle East.

\section{Observations}

Among 224 journal articles reviewed in this paper, 208 articles applied quantitative or qualitative research methods to deal with the SCRM processes, including risk identification, risk assessment, risk mitigation, and risk monitoring as discussed in Section 6. Some observations based on these 208 methodology articles are made in the following sub-sections.

\subsection{Quantitative versus qualitative methods}


Figure 4 illustrates the distribution of number of journal articles applying quantitative and qualitative methods between 2003 and 2013. Quantitative methods consist of analytical (e.g., mathematical programming, simulation, etc.) and empirical (e.g., exploratory factor analysis, structural equation modelling, etc.). There are 159 (76.44\%) articles using quantitative methods and 49 (23.56\%) applying qualitative methods. It is evident from Figure 4 that the number of articles using quantitative methods has been increasing since 2004, whereas the application of qualitative methods is steady. In 2013, the number of articles using quantitative methods is three times more than those applying qualitative methods. The only year in which the qualitative methods were more than quantitative methods is 2004. This underscores the fact that during initial years in the development of any new area, qualitative work plays an important role in terms of defining concepts, identifying factors, and developing frameworks followed by quantitative work focusing on assessment and evaluation tools. Most of the qualitative methods are applied for the risk identification (Cavinato, 2004; Chopra and Sodhi, 2004; Christopher and Peck, 2004) and risk management philosophy (Christopher and Lee, 2004; Giunipero and Eltantawy, 2004; Zsidisin et al., 2004). Thus, it is obvious that the qualitative methods are mainly used to categorize or identify risk and construct SCRM ideas.

\subsection{Applied quantitative methods}

Quantitative methods have been developed and applied extensively for SCRM. While some researchers used a single method, other scholars have focused on integrated approaches, combining two or more methods. Tables 7 and 8 show the individual and integrated research methods, respectively. Among 159 quantitative based articles, there are 119 articles using individual methods, and the number of articles proposing integrated methods is $40,74.84 \%$ versus $25.16 \%$. According to Table 7 , the most popular individual analytical approach is mathematical programming (47 out of 119 articles or $39.50 \%$ ), followed by newsvendor model (10 out of 119 articles or $8.40 \%$ ) and simulation (10 out of 119 articles or $8.40 \%$ ). Besides, the most popular individual empirical approach is multiple regression model (3 out of 119 articles or 2.52\%). Obviously, the empirical methods have attracted much less attention than the analytical methods, 7 vs. 112. One of the key reasons is that it is difficult for researchers to communicate with practitioners and gain access to industry to carry out empirical studies as mentioned in Section 3.

From Table 8, it is evident that the most prevalent integrated analytical approach is fuzzy based multi-objective mathematical programming (3 out of 40 articles or $7.50 \%$ ), followed by Fuzzy AHP ( 2 out of 40 articles or 5.00\%) and Fuzzy TOPSIS (2 out of 40 articles or $5.00 \%)$. Among the integrated analytical methods, we see that fuzzy methods, AHP, and DEA are the most common methods used along with others. This is not surprising as these methods are useful to tackle the difficulty of quantifying risk as it is inherently intangible in many cases. Similarly, the application of empirical methods is not as prevalent as that of analytical methods, 4 vs. 36 . 
Although the integrated methods have attracted less attention in the literature, certain techniques can be integrated to overcome the limitations or enhance the performance of the original methods. For instance, fuzzy set theory can be used to overcome the limitation of deterministic nature and exact value characteristic of multi-objective mathematical programming (Kumar et al., 2006; Wu et al., 2010; Ji and Zhu, 2012). In addition, AHP can be incorporated into a QFD approach in order to ensure consistency of judgments (Ho et al., 2011). Therefore, integrated methods will play a vital role in the area of SCRM in the future.

\subsection{SCRM processes}

All of the 208 quantitative and qualitative based articles are classified according to the four major SCRM processes in Table 9. This classification clearly identifies the most widely studied process, and more importantly, depicts the relationships between particular research methods and SCRM processes. First, Table 9 clearly shows that the majority of researchers studied the individual process (143 quantitative plus 28 qualitative based articles, 171 articles in total or $82.21 \%$ ) rather than the integrated processes (16 quantitative plus 21 qualitative based articles, 37 articles in total or 17.79\%). Even with the integrated processes, researchers focused on two SCRM processes generally as revealed in Section 6.2. As there is a significant relationship between all SCRM processes, more attention should be given to legitimately integrated processes instead of individual or fragmented processes. Second, among 171 articles focusing on the individual process, it is evident that the risk mitigation process (84 quantitative plus 17 qualitative based articles, 101 articles in total or 59.06\%) has attracted the most attention. With respect to the quantitative methods, the application of analytical methods is much more than that of empirical methods (78 vs. 6 articles). Third, risk assessment is the second most widely studied process (56 quantitative plus 6 qualitative based articles, 62 articles in total or 36.26\%). Similarly, 54 out of 56 quantitative based articles applied analytical methods in the risk assessment process. It is not a surprise that the risk assessment and mitigation processes are widely covered by quantitative methods since risk assessment includes quantifying the likelihood and impact of risky events. Similarly, the effectiveness of risk mitigation strategies requires explicit quantification of effectiveness and efficiency of such strategies. Moreover, risk mitigation naturally lends itself to prediction and prescription, which quantitative methods focus on. Surprisingly, in the last eleven years, there is only one article studying the risk monitoring process in a comprehensive manner (Zhang et al., 2011). Fourth, among 37 articles focusing on the integrated processes, the application of qualitative methods is slightly more than that of quantitative methods (21 vs. 16 articles). As discussed in Sections 6.2.1 and 6.2.2, the qualitative approaches used in the integrated processes are conceptual in nature or they simply explain the steps or phases but do not demonstrate how the approaches can be applied.

\subsection{Risk types focused}

Among the 208 methodology based articles, 140 of them focused on specific risk types, whereas 68 of them simply proposed methods to deal with generic risks. Table 10 
demonstrates the distribution of 140 articles in terms of risk types. The most widely studied risk type is the supply risk (70 articles). As mentioned in Sections 6.1.2.4 and 6.1.3.4, most of the researchers studied the supplier assessment and mitigation problems with risk considerations. Demand risk (39 articles) and manufacturing risk (13 articles) are the second and third commonly focused risk types, respectively. This is consistent with the findings in Section 4 that demand, manufacturing, and supply risks have attracted the most attention. Besides, the majority of the articles focused on a particular risk type. Only three out of 140 articles studied two risk types simultaneously (Goh et al., 2007; Qiang and Nagurney, 2012; Baghalian et al., 2013). This is a gap that can be addressed by future work in this domain.

\subsection{Application areas}

From Table 11, we observe that 18 areas or industries have been studied. The majority of the articles focused on a particular industry (59 out of 67 articles, or 88.06\%). Eight out of 67 articles focused on two or more industries (Zsidisin et al., 2004; Zsidisin et al., 2005; Wagner and Bode, 2008; Blos et al., 2009; Wagner and Neshat, 2010; Blome and Schoenherr, 2011; Christopher et al., 2011; Kern et al., 2012). The most popular application area is the automotive industry (15 articles), followed by electronics industry (12 articles) and aerospace industry (9 articles). It shows that the SCRM methods have been widely applied to manufacturing supply chains (84 articles) whereas service supply chains (6 articles) are fairly unexplored. Given the importance of service supply chains, it is critical for researchers to place more focus on managing risks in this area. Besides, all the applications are limited to the private sector, and there is no article focusing on the public sector.

\section{Research gaps and recommendations}

Opportunities for further research in the area of SCRM are abundant. We find that the supply risk holds a very large proportion of all risk types, while other risk types received limited consideration, especially the infrastructural risk. There is clearly a research gap in the domain of infrastructural risks such as transportation, information, and financial risk as well as macro risks. Since infrastructure plays a critical role in managing supply chain effectively, the emphasis on managing and mitigating these types of risks is important as we move forward. Also, in comparison to demand and supply risks, the area of manufacturing or process risk has not received much attention, which is another key avenue for future research.

Every organization may face all the five suggested risk types. While focusing on a particular risk type has its advantages, interdependencies and interrelationships among various risk types is certainly an issue that needs to be further explored. Investigating the joint impact of such risks can lead to better management of supply chains than treating each risk type in isolation. This is an area that we recommend scholars in this domain to consider as we move forward. 
There exists an abundant set of factors, which would give rise to supply chain disruptions. However, there is lack of research measuring the correlations between risk factors and corresponding risk types, or the probability of occurrence of particular risk types associated with their factors. Field and case studies are necessary to investigate and estimate such correlations and focus on developing methods to evaluate the probabilities of occurrence of particular risk types so that methods can be developed to appease such risks through mitigation strategies.

Although there is an increasing amount of research in the area of SCRM, most of them are theoretical in nature. For instance, a wide variety of SCRM management methods and conceptual frameworks have emerged, however, they have not been validated empirically. To fill this gap, scholars could use primary data to investigate the applicability and effectiveness of those SCRM models in practical situations. Besides, scholars could also assess the adaptability and flexibility of the SCRM models by applying them to different companies in the same or different sectors, and in the same or different countries.

Some sectors have been underrepresented over the past decade. For instance, the public sector has not been fully investigated. As many governments in the globe are exposed to various internal and external risks, further knowledge can be contributed. Similarly, the renewable energy sector has not been a part of any specific research. Specifically, bioenergy projects are especially vulnerable to risks associated with the biomass supply chain. For example, the type and reliable supply of biomass is important as not all biomass is compatible with all boiler systems. The incorrect choice of biomass and supplier can lead to project failure (Scott et al., 2013).

The majority of scholars focused on manufacturing supply chains (e.g., automotive, electronics, aerospace, and so on), whereas service supply chains have attracted much less attention in the past decade. In view of the important role of service industry (e.g., banking, insurance, health-care, and so on) in present economy, the literature relating to service based SCRM must be enriched.

It is evident that the risk monitoring process has received the least attention by researchers compared with the other three processes, including risk identification, risk assessment, and risk mitigation. Among all 224 articles reviewed, there is only one article studying early warning monitoring of risks in the food manufacturing supply chains (Zhang et al., 2011). As a robust risk prevention system is more cost-effective than risk mitigation in practice, scholars should extend the literature by developing an early warning monitoring system with adaptive risk indicators for various types of supply chains and validating the system empirically.

As discussed, risk mitigation has been extensively studied with a wide range of mitigation strategies proposed. However, there is lack of research in benchmarking these strategies. Researchers and practitioners have not comprehensively addressed the selection of 
the most appropriate strategies in particular scenarios. In most cases, the efficacy of a specific strategy is investigated in extant research. Although Talluri et al. (2013) attempted to evaluate seven individual risk mitigation strategies under different scenarios, they did not consider the joint impact of these strategies. To fill this research gap, scholars could evaluate and select the best mitigation strategies among various individual and integrated strategies with respect to both efficiency and effectiveness.

There exist a number of conceptual frameworks and approaches covering all four SCRM processes. Besides risk identification, risk assessment, risk mitigation, and risk monitoring, risk recovery should also be studied and incorporated into the SCRM approaches so as to enable the supply chain to quickly return to its original state during the occurrence of a disruption. Although Hishamuddin et al. (2013) studied the recovery aspect, their focus was on recovery schedule instead of recovery strategies/methods for a simple two-tier supply chain with one supplier and one retailer. In view of its importance, but scarce studies on risk recovery, scholars could expand the existing SCRM approaches by incorporating a risk recovery phase.

Finally, it would be worthwhile to quantify the benefits and costs of SCRM. For example, scholars could measure the value added to the organizations after implementing SCRM methods/strategies. Besides, scholars could apply a multiple case study approach to analyze and benchmark the payoffs or losses between those companies incorporating SCRM and non-SCRM adopters in the same sector while exposing to similar risk types. These studies would attract more organizations focusing on SCRM, and also shed light on effective practices for implementing SCRM to receive the maximum payoff.

\section{Conclusions}

In this paper, we reviewed 224 international journal articles appearing between 2003 and 2013 targeting the area of SCRM. We categorized all these articles according to definitions, types, factors, and SCRM methods. This paper made several contributions to the field of SCRM. First, we provided a new definition to supply chain risk and SCRM. The new definitions are clearer and more specific than the existing ones, and enable a common understanding between researchers and practitioners. This will not only help researchers communicate with practitioners and gain access to industry to conduct empirical studies, but also help researchers identify and measure the likelihood and impact of the entire supply chain risks, and evaluate the effectiveness of supply chain risk management methodologies. Second, we proposed five common risks arising across various types of supply chains, including macro risk, demand risk, manufacturing risk, supply risk, and infrastructural risk (information risk, transportation risk, and financial risk). This comprehensive classification could help researchers and practitioners identify various risk types with differing degrees of impact that are both external and internal to supply chains. Third, combining various points of views of scholars, we created a holistic list of potential factors affecting the five common risk types. This will not only help researchers and practitioners identify and classify the 
potential risk factors, but also provide a starting point for creating a supply chain risk index model. Fourth, we classified both quantitative and qualitative SCRM methods according to four major SCRM processes, including risk identification, risk assessment, risk mitigation, and risk monitoring. This will provide useful insights to researchers and practitioners for SCRM, such as which methods (qualitative vs. quantitative; individual and integrated) are applicable in particular SCRM processes. Fifth, we revealed ten research gaps and proposed corresponding potential research directions in the area of SCRM. We hope our recommendations for further research directions would aid academics conduct more impactful studies in SCRM, which in turn assists practitioners in managing supply chain risks more effectively and efficiently via knowledge transfer.

While we have considered a comprehensive evaluation of SCRM work, our research is not devoid of limitations. There are three main limitations of this paper. First, we only reviewed international journal articles, while excluding the conference papers, master and doctoral dissertations, textbooks, book chapters, unpublished articles, and notes. Second, this paper is solely based on the analyses from the point of view of academics while failing to incorporate the views of practitioners. Third, the goal of this study was to present and categorize recent SCRM research and explore potential research gaps. With that in mind, an overarching question is not posed as usually done in more specific literature reviews. Using the categorization and summary results of this paper, further studies can delve into specific areas that have been under-researched and extend studies that have focused on mature areas of SCRM.

\section{Acknowledgements}

The authors would like to acknowledge the three anonymous reviewers for their insightful and constructive comments, and the financial support received by one of the authors from the Faculty of Business and Economics, The University of Melbourne. 


\section{References}

Adhitya, A., Srinivasan, R., Karimi, I.A., 2009. Supply chain risk identification using a HAZOP-based approach. American Institute of Chemical Engineers 55, 1447-1463.

Aggarwal, P., Ganeshan, R., 2007. Using risk-management tools on B2Bs: An exploratory investigation. International Journal of Production Economics 108, $2-7$.

Arcelus, F.J., Kumar, S., Srinivasan, G., 2012. Risk tolerance and a retailer's pricing and ordering policies within a newsvendor framework. Omega 40, 188-198.

Azad, N., Davoudpour, H., 2013. Designing a stochastic distribution network model under risk. International Journal Advanced Manufacturing Technology 64, 23-40.

Azadeh, A., Alem, S.M., 2010. A flexible deterministic, stochastic and fuzzy data envelopment analysis approach for supply chain risk and vendor selection problem: Simulation analysis. Expert Systems with Applications 37, 7438-7448.

Azaron, A., Brown, K.N., Tarim, S.A., Modarres, M., 2008. A multi-objective stochastic programming approach for supply chain design considering risk. International Journal of Production Economics 116, 129-138.

Baghalian, A., Rezapour, S., Farahani, R.Z., 2013. Robust supply chain network design with service level against disruptions and demand uncertainties: A real-life case. European Journal of Operational Research 227, 199-215.

Bakshi, N., Kleindorfer, P., 2009. Co-opetition and investment for supply-chain resilience. Production and Operations Management 18, 583-603.

Ballou, R.H., Burnetas, A., 2003. Planning multiple location inventories. Journal of Business Logistics 24, 65-89.

Bandaly, D., Satir, A., Kahyaoglu, Y., Shanker, L., 2012. Supply chain risk management - I: Conceptualization, framework and planning process. Risk Management 14, 249-271.

Ben-Tal, A., Chung, B.D., Mandala, S.R., Yao, T., 2011. Robust optimization for emergency logistics planning: Risk mitigation in humanitarian relief supply chains. Transportation Research Part B 45, 1177-1189.

Berger, P.D., Gerstenfeld, A., Zeng, A.Z., 2004. How many suppliers are best? A decisionanalysis approach. Omega 32, 9-15.

Berle, Ø., Norstad, I., Asbjørnslett, B.E., 2013. Optimization, risk assessment and resilience in LNG transportation systems. Supply Chain Management: An International Journal 18, 253-264.

Betts, J.M., Johnston, R.B., 2005. Just-in-time component replenishment decisions for assemble-to-order manufacturing under capital constraint and stochastic demand. International Journal of Production Economics 95, 51-70.

Blackhurst, J.V., Scheibe, K.P., Johnson, D.J., 2008. Supplier risk assessment and monitoring for the automotive industry. International Journal of Physical Distribution \& Logistics Management 38, 143-165.

Blome, C., Schoenherr, T., 2011. Supply chain risk management in financial crises - A multiple case-study approach. International Journal of Production Economics 134, 4357. 
Blos, M.F., Quaddus, M., Wee, H.M., Watanabe, K., 2009. Supply chain risk management (SCRM): A case study on the automotive and electronic industries in Brazil. Supply Chain Management: An International Journal 14, 247-252.

Bogataj, D., Bogataj, M., 2007. Measuring the supply chain risk and vulnerability in frequency space. International Journal of Production Economics 108, 291-301.

Braunscheidel, M.J., Suresh, N.C., 2009. The organizational antecedents of a firm's supply chain agility for risk mitigation and response. Journal of Operations Management 27, 119-140.

Brun, A., Caridi, M., Salama, K.F., Ravelli, I., 2006. Value and risk assessment of supply chain management improvement projects. International Journal of Production Economics 99, 186-201.

Cachon, G.P., 2004. The allocation of inventory risk in a supply chain: push, pull, and advance-purchase discount contracts. Management Science 50, 222-238.

Cavinato, J.L., 2004. Supply chain logistics risks: From the back room to the board room. International Journal of Physical Distribution \& Logistics Management 34, 383-387.

Chan, F.T.S., Kumar, N., 2007. Global supplier development considering risk factors using fuzzy extended AHP-based approach. Omega 35, 417-431.

Chaudhuri, A., Mohanty, B.K., Singh, K.N., 2013. Supply chain risk assessment during new product development: A group decision making approach using numeric and linguistic data. International Journal of Production Research 51, 2790-2804.

Chen, F.Y., Yano, C.A., 2010. Improving supply chain performance and managing risk under weather-related demand uncertainty. Management Science 56, 1380-1397.

Chen, H., Chen, J., Chen, Y., 2006. A coordination mechanism for a supply chain with demand information updating. International Journal of Production Economics 103, 347-361.

Chen, J., Sohal, A.S., Prajogo, D.I., 2013. Supply chain operational risk mitigation: A collaborative approach. International Journal of Production Research 57, 2186-2199.

Chen, P.S., Wu, M.T., 2013. A modified failure mode and effects analysis method for supplier selection problems in the supply chain risk environment: A case study, Computers \& Industrial Engineering 66, 634-642.

Cheng, S.K., Kam, B.H., 2008. A conceptual framework for analysing risk in supply networks. Journal of Enterprise Information Management 22, 345-360.

Cheong, T., Song., H.S., 2013. The value of information on supply risk under random yields. Transportation Research Part E 60, 27-38.

Chiu, C.H., Choi, T.M., Li, X., 2011. Supply chain coordination with risk sensitive retailer under target sales rebate. Automatica 47, 1617-1625.

Choi, T.Y., Krause, D.R., 2006. The supply base and its complexity: Implications for transaction costs, risks, responsiveness, and innovation. Journal of Operations Management 24, 637-652.

Chopra, S., Reinhardt, G., Mohan, U., 2007. The importance of decoupling recurrent and disruption risks in a supply chain. Naval Research Logistics, 54, 544-555. 
Chopra, S., Sodhi, M.S., 2004. Managing risk to avoid supply-chain breakdown. MIT Sloan Management Review 46, 53-62.

Chopra, S., Sodhi, M.S., 2014. Reducing the risk of supply chain disruptions. MIT Sloan Management Review 55, 73-80.

Christopher, M., Lee, H., 2004. Mitigating supply chain risk through improved confidence. International Journal of Physical Distribution \& Logistics Management 34, 388-396.

Christopher, M., Mena, C., Khan, O., Yurt, O., 2011. Approaches to managing global sourcing risk. Supply Chain Management: An International Journal 16, 67-81.

Christopher, M., Peck, H., 2004. Building the resilient supply chain. The International Journal of Logistics Management 15, 1-13.

Cigolini, R., Rossi, T., 2010. Managing operational risks along the oil supply chain. Production Planning \& Control 21, 452-467.

Colicchia, C., Dallari, F., Melacini, M., 2010. Increasing supply chain resilience in a global sourcing context. Production Planning \& Control 21, 680-694.

Colicchia, C., Strozzi, F., 2012. Supply chain risk management: A new methodology for a systematic literature review. Supply Chain Management: An International Journal 17, 403-418.

Costantino, N., Pellegrino, R., 2010. Choosing between single and multiple sourcing based on supplier default risk: A real options approach. Journal of Purchasing \& Supply Management 16, 27-40.

Craighead, C.W., Blackhurst, J., Rungtusanatham, M.J., Handfield, R.B., 2007. The severity of supply chain disruptions: Design characteristics and mitigation capabilities. Decision Sciences 38, 131-156.

Crnkovic, J., Tayi, G.K., Ballou, D.P, 2008. A decision-support framework for exploring supply chain tradeoffs. International Journal of Production Economics 115, 28-38.

Cruz, J.M., 2009. The impact of corporate social responsibility in supply chain management: Multicriteria decision-making approach. Decision Support Systems 48, 224-236.

Cruz, J.M., 2013. Mitigating global supply chain risks through corporate social responsibility. International Journal of Production Research 51, 3995-4010.

Cruz, J.M., Nagurney, A., Wakolbinger, T., 2006. Financial engineering of the integration of global supply chain networks and social networks with risk management. Naval Research Logistics 53, 675-696.

Cucchiella, F., Gastaldi, M., 2006. Risk management in supply chain: A real option approach. Journal of Manufacturing Technology Management 17, 700-720.

Datta, S., Granger, C.W.J, Barari, M., Gibbs, T., 2007. Management of supply chain: An alternative modelling technique for forecasting. Journal of the Operational Research Society 58, 1459-1469.

Diabat, A., Govindan, K., Panicker, V.V., 2012. Supply chain risk management and its mitigation in a food industry. International Journal of Production Research 50, 30393050 . 
Diehl, D., Spinler, S., 2013. Defining a common ground for supply chain risk management A case study in the fast-moving consumer goods industry. International Journal of Logistics: Research and Applications 16, 311-327.

Dietrich, D.M., Cudney, E.A., 2011. Methods and considerations for the development of emerging manufacturing technologies into a global aerospace supply chain. International Journal of Production Research 49, 2819-2831.

Dowty, R.A., Wallace, W.A., 2010. Implications of organizational culture for supply chain disruption and restoration. International Journal of Production Economics 126, 57-65.

Du, T.C.T., Lee, H.M., Chen, A., 2003. Constructing federated databases in coordinated supply chains. Decision Support Systems 36, 49-64.

Durowoju, O.A., Chan, H.K., Wang, X., 2012. Entropy assessment of supply chain disruption. Journal of Manufacturing Technology Management 23, 998-1014.

Ellegaard, C., 2008. Supply risk management in a small company perspective. Supply Chain Management: An International Journal 13, 425-434.

Ellis, S.C., Henry, R.M., Shockley, J., 2010. Buyer perceptions of supply disruption risk: A behavioral view and empirical assessment. Journal of Operations Management 28, 3446.

Faisal, M.N., Banwet, D.K., Shankar, R., 2006. Supply chain risk mitigation: Modeling the enablers. Business Process Management Journal 12, 535-552.

Fang, J., Zhao, L., Fransoo, J.C., Woensel, T.V., 2013. Sourcing strategies in supply risk management: An approximate dynamic programming approach. Computers \& Operations Research 40, 1371-1382.

Foerstl, K., Reuter, C., Hartmann, E., Blome, C., 2010. Managing supplier sustainability risks in a dynamically changing environment - Sustainable supplier management in the chemical industry. Journal of Purchasing \& Supply Management 16, 118-130.

Franca, R.B., Jones, E.C., Richards, C.N., Carlson, J.P., 2010. Multi-objective stochastic supply chain modeling to evaluate tradeoffs between profit and quality. International Journal of Production Economics 127, 292-299.

Gaudenzi, B., Borghesi, A., 2006. Managing risks in the supply chain using the AHP method. The International Journal of Logistics Management 17, 114-136.

Georgiadis, M.C., Tsiakis, P., Longinidis, P., Sofioglou, M.K., 2011. Optimal design of supply chain networks under uncertain transient demand variations. Omega 39, 254272.

Ghadge, A., Dani, S., Chester, M., Kalawsky, R., 2013. A systems approach for modelling supply chain risks. Supply Chain Management: An International Journal 18, 523-538.

Giannakis, M., Louis, M., 2011. A multi-agent based framework for supply chain risk management. Journal of Purchasing \& Supply Management 17, 23-31.

Giri, B.C., 2011. Managing inventory with two suppliers under yield uncertainty and risk aversion. International Journal of Production Economics 133, 80-85. 
Giunipero, L.C., Eltantawy, R.A., 2004. Securing the upstream supply chain: A risk management approach. International Journal of Physical Distribution \& Logistics Management 34, 698-713.

Glock, C.H., Ries, J.M., 2013. Reducing lead time risk through multiple sourcing: The case of stochastic demand and variable lead time. International Journal of Production Research 51, 43-56.

Goh, M., Lim, J.Y.S., Meng, F., 2007. A stochastic model for risk management in global supply chain networks. European Journal of Operational Research 182, 164-173.

Grötsch, V.M., Blome, C., Schleper, M.C., 2013. Antecedents of proactive supply chain risk management - A contingency theory perspective. International Journal of Production Research 51, 2842-2867.

Gümüş, M., Ray, S., Gurnani, H., 2012. Supply-side story: Risks, guarantees, competition, and information asymmetry. Management Science 58, 1694-1714.

Guo, Z., Fang, F., Whinston, A.B., 2006. Supply chain information sharing in a macro prediction market. Decision Support Systems 42, 1944-1958.

Hahn, G.J., Kuhn, H., 2012a. Value-based performance and risk management in supply chains: A robust optimization approach. International Journal of Production Economics 139, 135-144.

Hahn, G.J., Kuhn, H., 2012b. Designing decision support systems for value-based management: A survey and an architecture. Decision Support Systems 53, 591-598.

Hale, T., Moberg, C.R., 2005. Improving supply chain disaster preparedness: A decision process for secure site location. International Journal of Physical Distribution \& Logistics Management 35, 195-207.

Haleh, H., Hamidi, A., 2011. A fuzzy MCDM model for allocating orders to suppliers in a supply chain under uncertainty over a multi-period time horizon. Expert Systems with Applications 38, 9076-9083.

Hallikas, J., Karvonen, I., Pulkkinen, U., Virolainen, V.M., Tuominen, M., 2004. Risk management processes in supplier networks. International Journal of Production Economics 90, 47-58.

Hallikas, J., Puumalainen, K., Vesterinen, T., Virolainen, V.M., 2005. Risk-based classification of supplier relationships. Journal of Purchasing \& Supply Management 11, 72-82.

Harland, C., Brenchley, R., Walker, H., 2003. Risk in supply networks. Journal of Purchasing \& Supply Management 9, 51-62.

He, Y., 2013. Sequential price and quantity decisions under supply and demand risks, International Journal of Production Economics 141, 541-551.

He, Y., Zhang, J., 2008. Random yield risk sharing in a two-level supply chain. International Journal of Production Economics 112, 769-781.

Hishamuddin, H., Sarker, R.A., Essam, D., 2013. A recovery model for a two-echelon serial supply chain with consideration of transportation disruption. Computers \& Industrial Engineering 64, 552-561. 
Ho, W., Dey, P.K., Lockström, M., 2011. Strategic sourcing: A combined QFD and AHP approach in manufacturing. Supply Chain Management: An International Journal 16, 446-461.

Hofmann, E., 2011. Natural hedging as a risk prophylaxis and supplier financing instrument in automotive supply chains. Supply Chain Management: An International Journal 16, 128-141.

Huang, H.Y., Chou, Y.C., Chang, S, 2009. A dynamic system model for proactive control of dynamic events in full-load states of manufacturing chains. International Journal of Production Research 47, 2485-2506.

Hult, G.T.M., Craighead, C.W., Ketchen, D.J., 2010. Risk uncertainty and supply chain decisions: A real options perspective. Decision Sciences 41, 435-458.

Hung, K.T., Ryu, S., 2008. Changing risk preferences in supply chain inventory decisions, Production Planning \& Control 19, 770-780.

Hung, S.J., 2011. Activity-based divergent supply chain planning for competitive advantage in the risky global environment: A DEMATEL-ANP fuzzy goal programming approach. Expert Systems with Applications 38, 9053-9062.

Iakovou, E., Vlachos, D., Xanthopoulos, A., 2010. A stochastic inventory management model for a dual sourcing supply chain with disruptions. International Journal of Systems Science 41, 315-324.

Ji, G., Zhu, C., 2012. A study on emergency supply chain and risk based on urgent relief service in disasters. Systems Engineering Procedia 5, 313-325.

Jiang, B., Baker, R.C., Frazier, G.V., 2009. An analysis of job dissatisfaction and turnover to reduce global supply chain risk: Evidence from China. Journal of Operations Management 27, 169-184.

Johnson, N., Elliott, D., Drake, P., 2013. Exploring the role of social capital in facilitating supply chain resilience. Supply Chain Management: An International Journal 18, 324336

Jüttner, U., 2005. Supply chain risk management: Understanding the business requirements from a practitioner perspective. The International Journal of Logistics Management 16, 120-141.

Jüttner, U., Maklan, S., 2011. Supply chain resilience in the global financial crisis: An empirical study. Supply Chain Management: An International Journal 16, 246-259.

Jüttner, U., Peck, H., Christopher, M., 2003. Supply chain risk management: Outlining an agenda for future research. International Journal of Logistics: Research and Applications 6, 197-210.

Kang, J.H., Kim, Y.D., 2012. Inventory control in a two-level supply chain with risk pooling effect. International Journal of Production Economics 135, 116-124.

Kaya, M., Özer, Ö., 2009. Quality risk in outsourcing: Noncontractible product quality and private quality cost information. Naval Research Logistics 56, 669-685. 
Kayis, B., Karningsih, P.D., 2012. A knowledge-based system tool for assisting manufacturing organizations in identifying supply chain risks. Journal of Manufacturing Technology Management 23, 834-852.

Kenné, J.P., Dejax, P., Gharbi, A., 2012. Production planning of a hybrid manufacturingremanufacturing system under uncertainty within a closed-loop supply chain. International Journal of Production Economics 135, 81-93.

Keren, B., 2009. The single-period inventory problem: Extension to random yield from the perspective of the supply chain. Omega 37, 801-810.

Kern, D., Moser, R., Hartmann, E., Moder, M., 2012. Supply risk management: Model development and empirical analysis. International Journal of Physical Distribution \& Logistics Management 42, 60-82.

Khan, O., Christopher, M., Burnes, B., 2008. The impact of product design on supply chain risk: A case study. International Journal of Physical Distribution \& Logistics Management 38, 412-432.

Khilwani, N., Tiwari, M.K., Sabuncuoglu, I., 2011. Hybrid Petri-nets for modelling and performance evaluation of supply chains. International Journal of Production Research 49, 4627-4656.

Kim, S.H., Fowler, J.W., Shunk, D.L., Pfund, M.E., 2012. Improving the push-pull strategy in a serial supply chain by a hybrid push-pull control with multiple pulling points. International Journal of Production Research 50, 5651-5668.

Kim, W.S., 2013. A supply chain contract with flexibility as a risk-sharing mechanism for demand forecasting, International Journal of Systems Science, 44, 1134-1149.

Kleindorfer, P.R., Saad, G.H., 2005. Managing disruption risks in supply chains. Production and Operations Management 14, 53-68.

Knemeyer, A.M., Zinn, W., Eroglu, C., 2009. Proactive planning for catastrophic events in supply chains. Journal of Operations Management 27, 141-153.

Kull, T.J., Talluri, S., 2008. A supply risk reduction model using integrated multicriteria decision making. IEEE Transactions on Engineering Management 55, 409-419.

Kull, T., Closs, D., 2008. The risk of second-tier supplier failures in serial supply chains: Implications for order policies and distributor autonomy. European Journal of Operational Research 186, 1158-1174.

Kumar, M., Vrat, P., Shankar, R., 2006. A fuzzy programming approach for vendor selection problem in a supply chain. International Journal of Production Economics 101, 273285.

Kumar, S., Havey, T., 2013. Before and after disaster strikes: A relief supply chain decision support framework. International Journal of Production Economics 145, 613-629.

Kumar, S.K., Tiwari, M.K., 2013. Supply chain system design integrated with risk pooling, Computers \& Industrial Engineering 64, 580-588.

Kumar, S.K., Tiwari, M.K., Babiceanu, R.F. 2010. Minimisation of supply chain cost with embedded risk using computational intelligence approaches. International Journal of Production Research 48, 3717-3739. 
Laeequddin, M., Sardana, G.D. Sahay, B.S., Waheed, K.A., Sahay, V., 2009. Supply chain partners' trust building process through risk evaluation: The perspectives of UAE packaged food industry. Supply Chain Management: An International Journal 14, 280 290.

Lavastre, O., Gunasekaran, A., Spalanzani, A., 2012. Supply chain risk management in French companies. Decision Support Systems 52, 828-838.

Le, H.Q., Arch-int, S., Nguyen, H.X., Arch-int, N., 2013. Association rule hiding in risk management for retail supply chain collaboration. Computers in Industry 64, 776-784.

Leat, P., Revoredo-Giha, C., 2013. Risk and resilience in agri-food supply chains: The case of the ASDA PorkLink supply chain in Scotland. Supply Chain Management: An International Journal 18, 219- 231.

Lei, D., Li, J., Liu, Z., 2012. Supply chain contracts under demand and cost disruptions with asymmetric information. International Journal of Production Economics 139, 116-126.

Lejeune, M.A., 2008. Preprocessing techniques and column generation algorithms for stochastically efficient demand. Journal of the Operational Research Society 59, 12391252.

Li, J., Wang, S., Cheng, T.C.E., 2010. Competition and cooperation in a single-retailer twosupplier supply chain with supply disruption. International Journal of Production Economics 124, 137-150.

Li, Q., 2007. Risk, risk aversion and the optimal time to produce. IIE Transactions 39, 145158.

Lin, Y., Zhou, L., 2011. The impacts of product design changes on supply chain risk: A case study. International Journal of Physical Distribution \& Logistics Management 41, 162186.

Liu, Z., Cruz, J.M., 2012. Supply chain networks with corporate financial risks and trade credits under economic uncertainty. International Journal of Production Economics 137, 55-67.

Liu, Z., Nagurney, A., 2011. Supply chain outsourcing under exchange rate risk and competition. Omega 39, 539-549.

Lockamy III, A., McCormack, K., 2010. Analysing risks in supply networks to facilitate outsourcing decisions. International Journal of Production Research 48, 593-611.

Lundin, J.F., 2012. Redesigning a closed-loop supply chain exposed to risks. International Journal of Production Economics 140, 596-603.

Mak, H.Y., Shen, Z.J.M., 2012. Risk diversification and risk pooling in supply chain design. IIE Transactions 44, 603-621.

Manuj, I., Mentzer, J.T., 2008. Global supply chain risk management strategies. International Journal of Physical Distribution \& Logistics Management 38, 192-223.

Meena, P.L., Sarmah, S.P., 2013. Multiple sourcing under supplier failure risk and quantity discount: A genetic algorithm approach. Transportation Research Part E 50, 84-97.

Meena, P.L., Sarmah, S.P., Sarkar, A. 2011. Sourcing decisions under risks of catastrophic event disruptions. Transportation Research Part E 47, 1058-1074. 
Nakashima, K., Gupta, S.M., 2012. A study on the risk management of multi Kanban system in a closed loop supply chain. International Journal of Production Economics 139, 6568.

Neiger, D., Rotaru, K., Churilov, L., 2009. Supply chain risk identification with valuefocused process engineering. Journal of Operations Management 27, 154-168.

Norrman, A., Jansson, U., 2004. Ericsson's proactive supply chain risk management approach after a serious sub-supplier accident. International Journal of Physical Distribution \& Logistics Management 34, 434-456.

Oehmen, J., Ziegenbein, A., Alard, R., Schönsleben, P., 2009. System-oriented supply chain risk management. Production Planning \& Control 20, 343-361.

Olson, D.L., Wu, D.D., 2010. A review of enterprise risk management in supply chain. Kybernetes 39, 694-706.

Olson, D.L., Wu, D., 2011. Risk management models for supply chain: A scenario analysis of outsourcing to China. Supply Chain Management: An International Journal 16, 401408.

Oke, A., Gopalakrishnan, M., 2009. Managing disruptions in supply chains: A case study of a retail supply chain. International Journal of Production Economics 118, 168-174.

Park, S., Lee, T.E., Sung, C.S., 2010. A three-level supply chain network design model with risk-pooling and lead times. Transportation Research Part E 46, 563-581.

Peck, H., 2005. Drivers of supply chain vulnerability: An integrated framework. International Journal of Physical Distribution \& Logistics Management 35, 210-232.

Pettit, T.J., Croxton, K.L., Fiksel, J., 2013. Ensuring supply chain resilience: Development and implementation of an assessment tool. Journal of Business Logistics 34, 46-76.

Poojari, C.A., Lucas, C., Mitra, G., 2008. Robust solutions and risk measures for a supply chain planning problem under uncertainty. Journal of the Operational Research Society 59, 2-12.

Pujawan, I.N., Geraldin, L.H., 2009. House of risk: A model for proactive supply chain risk management. Business Process Management Journal 15, 953-967.

Qiang, P., Nagurney, A., 2012. A bi-criteria indicator to assess supply chain network performance for critical needs under capacity and demand disruptions. Transportation Research Part A 46, 801-812.

Radke, A.M., Tseng, M.M., 2012. A risk management-based approach for inventory planning of engineering-to-order production. CIRP Annals-Manufacturing Technology 61, 387390.

Raghavan, N.R.S., Mishra, V.K., 2011. Short-term financing in a cash-constrained supply chain. International Journal of Production Economics 134, 407-412.

Rao, S., Goldsby, T.J., 2009. Supply chain risks: A review and typology. The International Journal of Logistics Management 20, 97-123.

Rao, U.S., Swaminathan, J.M., Zhang, J., 2005. Demand and production management with uniform guaranteed lead time. Production and Operations Management 14, 400-412. 
Ravindran, A.R., Bilsel, R.U., Wadhwa, V., Yang, T., 2010. Risk adjusted multicriteria supplier selection models with applications. International Journal of Production Research 48, 405-424.

Reiner, G., Fichtinger, J., 2009. Demand forecasting for supply processes in consideration of pricing and market information. International Journal of Production Economics 118, 55-62.

Ritchie, B., Brindley, C., 2007. An emergent framework for supply chain risk management and performance measurement. Journal of the Operational Research Society 58, 13981411.

Ruiz-Torres, A.J., Mahmoodi, F., 2007. The optimal number of suppliers considering the costs of individual supplier failures. Omega 35, 104-115.

Ruiz-Torres, A.J., Mahmoodi, F., Zeng, A.Z., 2013. Supplier selection model with contingency planning for supplier failures. Computers \& Industrial Engineering 66, 374-382.

Samvedi, A., Jain, V., Chan, F.T.S., 2013. Quantifying risks in a supply chain through integration of fuzzy AHP and fuzzy TOPSIS. International Journal of Production Research 51, 2433-2442.

Sawik, T., 2013a. Integrated selection of suppliers and scheduling of customer orders in the presence of supply chain disruption risks. International Journal of Production Research 51, 7006-7022.

Sawik, T., 2013b. Selection of resilient supply portfolio under disruption risks. Omega 41, 259-269.

Sayed, H.E., Gabbar, H.A., Miyazaki, S., 2009. A hybrid statistical genetic-based demand forecasting expert system. Expert Systems with Applications 36, 11662-11670.

Schmitt, A.J., 2011. Strategies for customer service level protection under multi-echelon supply chain disruption risk. Transportation Research Part B 45, 1266-1283.

Schmitt, A.J., Singh, M., 2012. A quantitative analysis of disruption risk in a multi-echelon supply chain. International Journal of Production Economics 139, $22-32$.

Schmitt, A.J., Snyder, L.V., Shen, Z.J.M., 2010. Inventory systems with stochastic demand and supply: Properties and approximations. European Journal of Operational Research 206, 313-328.

Schoenherr, T., Tummala, V.M.R, Harrison, T.P., 2008. Assessing supply chain risks with the analytic hierarchy process: Providing decision support for the offshoring decision by a US manufacturing company. Journal of Purchasing \& Supply Management 14, 100-111.

Scott, J.A., Ho, W., Dey, P.K., 2013. Strategic sourcing in the UK bioenergy industry. International Journal of Production Economics 146, 478-490.

Shi, Y., Wu, F., Chu, L.K., Sculli, D., Xu, Y.H., 2011. A portfolio approach to managing procurement risk using multi-stage stochastic programming. Journal of the Operational Research Society 62, 1958-1970. 
Shin, H., Benton, W.C., 2007. A quantity discount approach to supply chain coordination. European Journal of Operational Research 180, 601-616.

Sinha, P.R., Whitman, L.E., Malzahn, D., 2004. Methodology to mitigate supplier risk in an aerospace supply chain. Supply Chain Management: An International Journal 9, 154168.

Skipper, J.B., Hanna, J.B., 2009. Minimizing supply chain disruption risk through enhanced flexibility. International Journal of Physical Distribution \& Logistics Management 39, 404-427.

Smaros, J., Lehtonen, J.M., Appelqvist, P., Holmström, J., 2003. The impact of increasing demand visibility on production and inventory control efficiency. International Journal of Physical Distribution \& Logistics Management 33, 336-354.

Smith, G.E., Watson, K.J., Baker, W.H., Pokorski II, J.A., 2007. A critical balance: Collaboration and security in the IT-enabled supply chain. International Journal of Production Research 45, 2595-2613.

Snyder, L.V., Daskin, M.S., Teo, C.P., 2007. The stochastic location model with risk pooling. European Journal of Operational Research 179, 1221-1238.

Sodhi, M.S., 2005. Managing demand risk in tactical supply chain planning for a global consumer electronics company. Production and Operations Management 14, 69-79.

Sodhi, M.S., Son, B.G, Tang, C.S., 2012. Researchers' perspectives on supply chain risk management. Production and Operations Management 21, 1-13.

Sodhi, M.S., Tang, C.S., 2009. Modeling supply-chain planning under demand uncertainty using stochastic programming: A survey motivated by asset-liability management. International Journal of Production Economics 121, 728-738.

Son, J.Y., Orchard, R.K., 2013. Effectiveness of policies for mitigating supply disruptions. International Journal of Physical Distribution \& Logistics Management 43, 684-706.

Speier, C., Whipple, J.M., Closs, D.J., Voss, M.D., 2011. Global supply chain design considerations: Mitigating product safety and security risks. Journal of Operations Management 29, 721-736.

Sucky, E., 2009. The bullwhip effect in supply chains - An overestimated problem? International Journal of Production Economics 118, 311-322.

Sun, J., Matsui, M., Yin, Y., 2012. Supplier risk management: An economic model of P-chart considered due-date and quality risks. International Journal of Production Economics 139, 58-64.

Talluri, S., Cetin, K., Gardner, A.J., 2004. Integrating demand and supply variability into safety stock evaluations. International Journal of Physical Distribution \& Logistics Management 34, 62-69.

Talluri, S., Kull, T.J., Yildiz, H., Yoon, J., 2013. Assessing the efficiency of risk mitigation strategies in supply chains. Journal of Business Logistics 34, 253-269.

Talluri, S., Narasimhan, R., 2003. Vendor evaluation with performance variability: A maxmin approach. European Journal of Operational Research 146, 543-552. 
Talluri, S., Narasimhan, R., Chung, W., 2010. Manufacturer cooperation in supplier development under risk. European Journal of Operational Research 207, 165-173.

Talluri, S., Narasimhan, R., Nair, A., 2006. Vendor performance with supply risk: A chanceconstrained DEA approach. International Journal of Production Economics 100, 212222.

Tang, C.S., 2006a. Perspectives in supply chain risk management. International Journal of Production Economics 103, 451-488.

Tang, C.S., 2006b. Robust strategies for mitigating supply chain disruptions. International Journal of Logistics: Research and Applications 9, 33-45.

Tang, C.S., Tomlin, B., 2008. The power of flexibility for mitigating supply chain risks. International Journal of Production Economics 116, 12-27.

Tang, O., Musa, S.N., 2011. Identifying risk issues and research advancements in supply chain risk management. International Journal of Production Economics 133, 25-34.

Tang, O., Musa, S.N., Li, J., 2012. Dynamic pricing in the newsvendor problem with yield risks. International Journal of Production Economics 139, 127-134.

Tapiero, C.S., 2007. Consumers risk and quality control in a collaborative supply chain. European Journal of Operational Research 182, 683-694.

Tomlin, B., 2006. On the value of mitigation and contingency strategies for managing supply chain disruption risks. Management Science 52, 639-657.

Tomlin, B., 2009. Disruption-management strategies for short life-cycle products. Naval Research Logistics 56, 318-347.

Towill, D.R., 2005. The impact of business policy on bullwhip induced risk in supply chain management. International Journal of Physical Distribution \& Logistics Management 35, 555-575.

Thun, J., Hoenig, D., 2011. An empirical analysis of supply chain risk management in the German automotive industry. International Journal of Production Economics 131, 242249.

Trkman, P., McCormack, K., 2009. Supply chain risk in turbulent environments - A conceptual model for managing supply chain network risk. International Journal of Production Economics 119, 247-258.

Tsai, C.Y., 2008. On supply chain cash flow risks. Decision Support Systems 44, 1031-1042.

Tsai, M.C., Liao, C.H., Han, C.S., 2008. Risk perception on logistics outsourcing of retail chains: Model development and empirical verification in Taiwan. Supply Chain Management: An International Journal 13, 415-424.

Tse, Y.K., Tan, K.H., 2011. Managing product quality risk in a multi-tier global supply chain. International Journal of Production Research 49, 139-158.

Tummala, R., Schoenherr, T., 2011. Assessing and managing risks using the supply chain risk management process (SCRMP). Supply Chain Management: An International Journal 16, 474-483.

Tuncel, G., Alpan, G., 2010. Risk assessment and management for supply chain networks: A case study. Computers in Industry 61, 250-259. 
Vedel., M., Ellegaard, C., 2013. Supply risk management functions of sourcing intermediaries: An investigation of the clothing industry. Supply Chain Management: An International Journal 18, 509-522.

Viswanadham, N., Samvedi, A., 2013. Supplier selection based on supply chain ecosystem, performance and risk criteria, International Journal of Production Research 51, 64846498.

Wagner, S.M., Bode, C., 2006. An empirical investigation into supply chain vulnerability. Journal of Purchasing \& Supply Management 12, 301-312.

Wagner, S.M., Bode, C., 2008. An empirical examination of supply chain performance along several dimensions of risk. Journal of Business Logistics 29, 307-325.

Wagner, S.M., Neshat, N., 2010. Assessing the vulnerability of supply chains using graph theory. International Journal of Production Economics 126, 121-129.

Wagner, S.M., Silveira-Camargos, V., 2012. Managing risks in Just-in-sequence supply networks: Exploratory evidence from automakers. IEEE Transactions on Engineering Management 59, 52-64.

Wakolbinger, T., Cruz, J.M., 2011. Supply chain disruption risk management through strategic information acquisition and sharing and risk-sharing contracts. International Journal of Production Research 49, 4063-4084.

Wang, X., Chan, H.K., Yee, R.W.Y., Diaz-Rainey, I., 2012. A two-stage fuzzy-AHP model for risk assessment of implementing green initiatives in the fashion supply chain. International Journal of Production Economics 135, 595-606.

Wang, Y., Gilland, W., Tomlin, B., 2011. Regulatory trade risk and supply chain strategy. Production and Operations Management 20, 522-540.

Wiengarten, F., Pagell, M., Fynes, B., 2013. The importance of contextual factors in the success of outsourcing contracts in the supply chain environment: The role of risk and complementary practices. Supply Chain Management: An International Journal 18, 630-643.

Wu, D., Olson, D.L., 2008. Supply chain risk, simulation, and vendor selection. International Journal of Production Economics 114, 646-655.

Wu, D., Wu, D.D., Zhang, Y., Olson, D.L., 2013. Supply chain outsourcing risk using an integrated stochastic-fuzzy optimization approach. Information Sciences 235, 242-258.

Wu, D.D, Olson, D., 2010. Enterprise risk management: A DEA VaR approach in vendor selection. International Journal of Production Research 48, 4919-4932.

Wu, D.D., Zhang, Y., Wu, D., Olson, D.L., 2010. Fuzzy multi-objective programming for supplier selection and risk modeling: A possibility approach. European Journal of Operational Research 200, 774-787.

Wu, T., Blackhurst, J., Chidambaram, V., 2006. A model for inbound supply risk analysis. Computers in Industry 57, 350-365.

Wu, T., Blackhurst, J., O’grady, P., 2007. Methodology for supply chain disruption analysis. International Journal of Production Research 45, 1665-1682. 
Xanthopoulos, A., Vlachos, D., Iakovou, E., 2012. Optimal newsvendor policies for dualsourcing supply chains: A disruption risk management framework. Computers \& Operations Research 39, 350-357.

Xia, D., Chen, B., 2011. A comprehensive decision-making model for risk management of supply chain. Expert Systems with Applications 38, 4957-4966.

Xia, Y., Ramachandran, K., Gurnani, H., 2011. Sharing demand and supply risk in a supply chain. IIE Transactions 43, 451-469.

Xiao, T., Yang, D., 2008. Price and service competition of supply chains with risk-averse retailers under demand uncertainty. International Journal of Production Economics 114, 187-200.

Xiao, T., Yang, D., 2009. Risk sharing and information revelation mechanism of a onemanufacturer and one-retailer supply chain facing an integrated competitor. European Journal of Operational Research 196, 1076-1085.

Yang, B., Yang, Y., 2010. Postponement in supply chain risk management: A complexity perspective. International Journal of Production Research, 48, 1901-1912.

Yang, Z.B., Aydın, G., Babich, V., Beil, D.R., 2009. Supply disruptions, asymmetric information, and a backup production option. Management Science 55, 192-209.

Yu, H., Zeng, A.Z., Zhao, L., 2009. Single or dual sourcing: Decision-making in the presence of supply chain disruption risks. Omega 37, 788-800.

Zhang, K., Chai, Y., Yang, S.X., Weng, D., 2011. Pre-warning analysis and application in traceability systems for food production supply chains. Expert Systems with Applications 38, 2500-2507.

Zsidisin, G.A., 2003. A grounded definition of supply risk. Journal of Purchasing \& Supply Management 9, 217-224.

Zsidisin, G.A., Ellram, L.M., 2003. An agency theory investigation of supply risk management. The Journal of Supply Chain Management 8, 15-26.

Zsidisin, G.A., Ellram, L.M., Carter, J.R., Cavinato, J.L., 2004. An analysis of supply risk assessment techniques. International Journal of Physical Distribution \& Logistics Management 34, 397-413.

Zsidisin, G.A., Melnyk, S.A., Ragatz, G.L., 2005. An institutional theory perspective of business continuity planning for purchasing and supply management. International Journal of Production Research, 43(16), 3401-3420.

Zsidisin, G.A., Smith, M.E., 2005. Managing supply risk with early supplier involvement: A case study and research propositions. The Journal of Supply Chain Management 11, 44-57. 


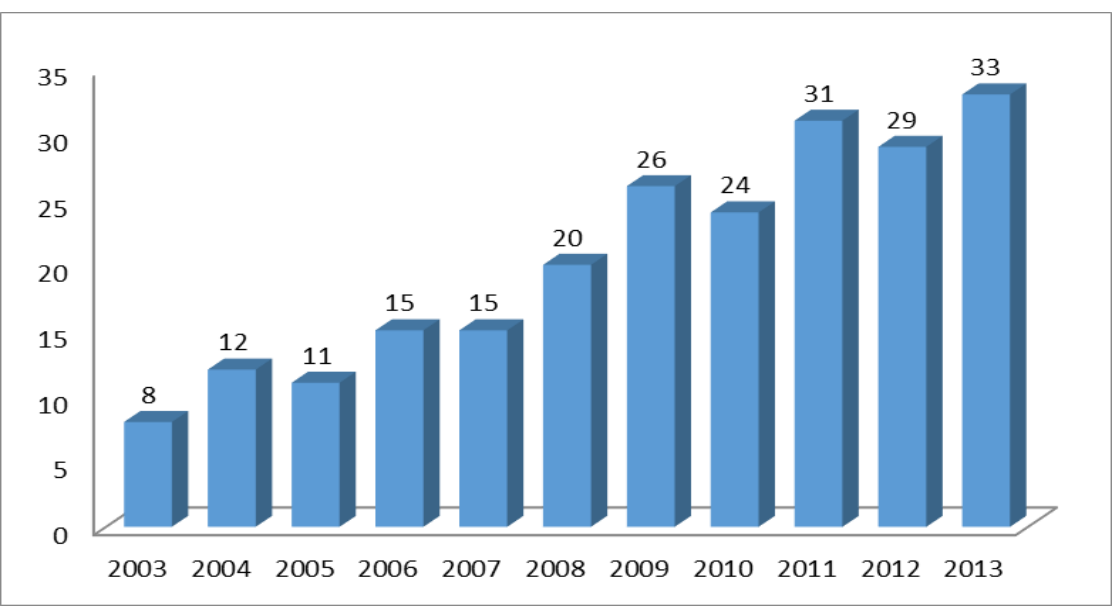

Figure 1. Distribution of number of journal articles over the last 11 years.

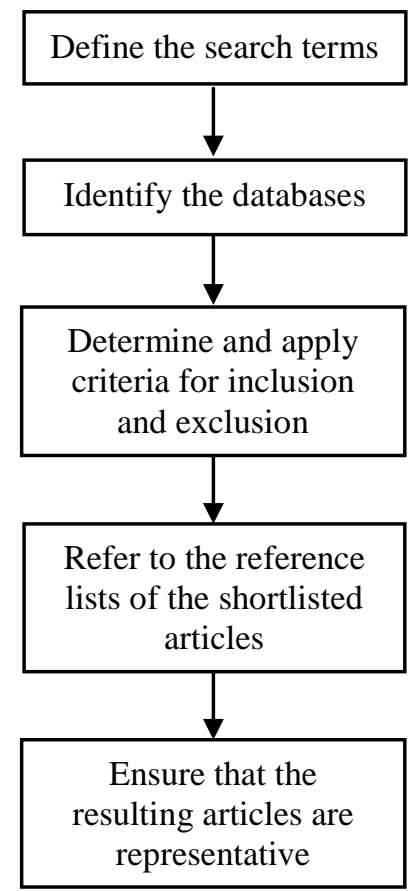

Figure 2. Flowchart of the research methodology. 


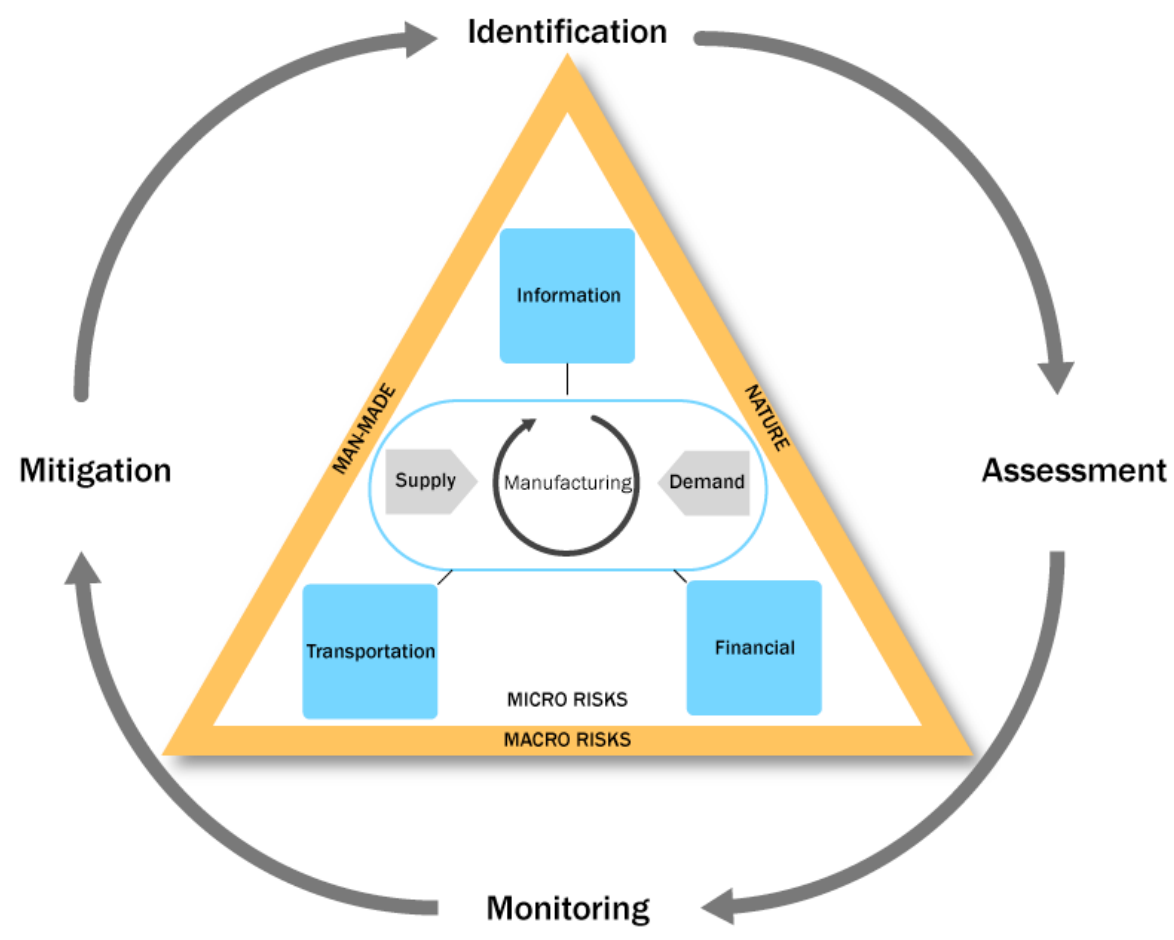

Figure 3. Conceptual framework of supply chain risks.

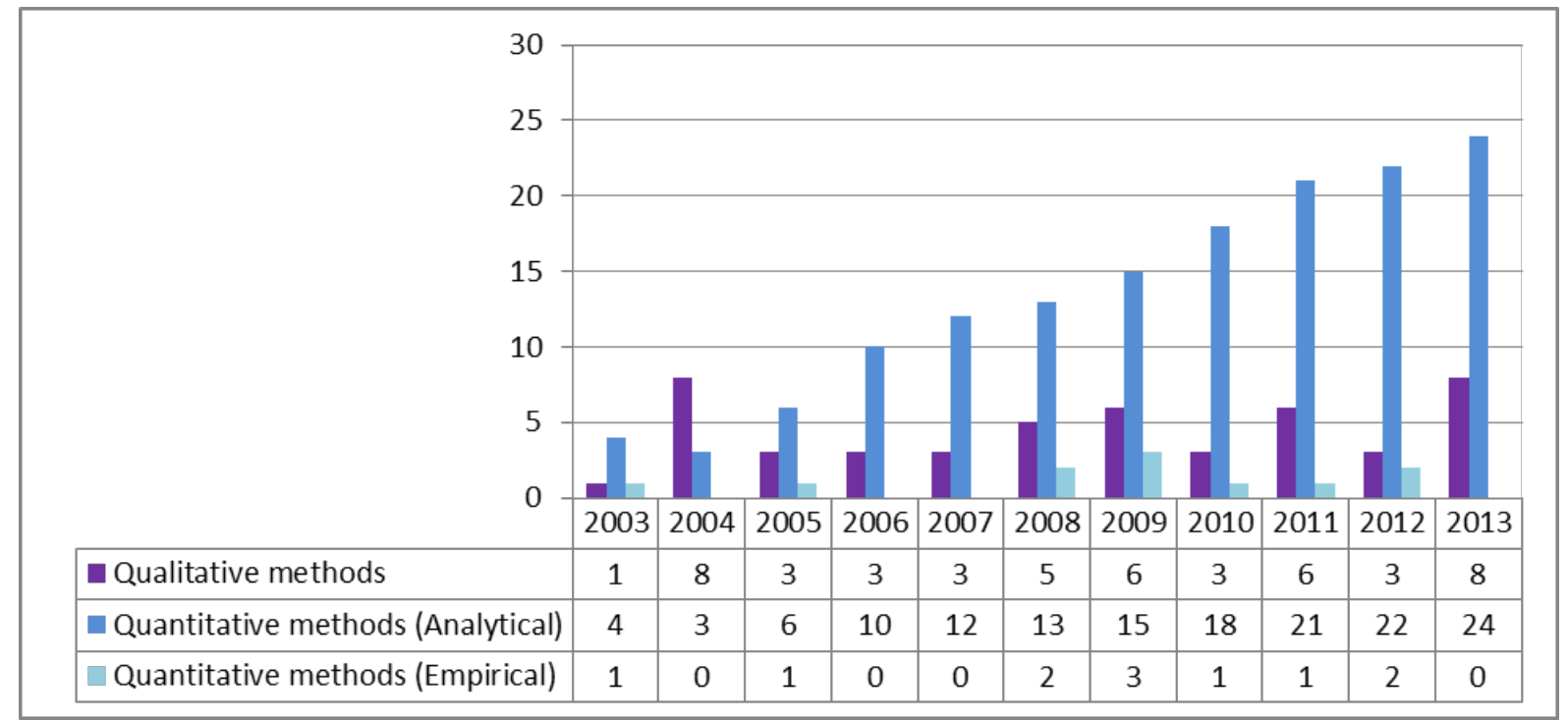

Figure 4. Distribution of number of quantitative and qualitative methods over the last 11 years. 
Table 1. A summary of topics covered by previous SCRM review articles.

\begin{tabular}{|c|c|c|c|c|c|c|c|c|c|c|c|c|}
\hline & & 2003 & 2004 & 2005 & 2006 & 2007 & 2008 & 2009 & 2010 & 2011 & 2012 & 2013 \\
\hline \multirow{4}{*}{ 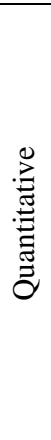 } & Risk classification & $\begin{array}{l}\text { Tang and } \\
\text { Musa } \\
\text { (2011) }\end{array}$ & $\begin{array}{l}\text { Tang and } \\
\text { Musa } \\
\text { (2011) }\end{array}$ & $\begin{array}{l}\text { Tang and } \\
\text { Musa } \\
\text { (2011) }\end{array}$ & $\begin{array}{l}\text { Tang and } \\
\text { Musa } \\
\text { (2011) }\end{array}$ & $\begin{array}{l}\text { Tang and } \\
\text { Musa } \\
\text { (2011) }\end{array}$ & $\begin{array}{l}\text { Tang and } \\
\text { Musa } \\
\text { (2011) }\end{array}$ & & & & & \\
\hline & Risk factor analysis & $\begin{array}{l}\text { Rao and } \\
\text { Goldsby } \\
\text { (2009) }\end{array}$ & $\begin{array}{l}\text { Rao and } \\
\text { Goldsby } \\
\text { (2009) }\end{array}$ & $\begin{array}{l}\text { Rao and } \\
\text { Goldsby } \\
\text { (2009) }\end{array}$ & $\begin{array}{l}\text { Rao and } \\
\text { Goldsby } \\
\text { (2009) }\end{array}$ & $\begin{array}{l}\text { Rao and } \\
\text { Goldsby } \\
\text { (2009) }\end{array}$ & $\begin{array}{l}\text { Rao and } \\
\text { Goldsby } \\
\text { (2009) }\end{array}$ & & & & & \\
\hline & Risk management methods & $\begin{array}{l}\text { Tang } \\
\text { (2006a) }\end{array}$ & $\begin{array}{l}\text { Tang } \\
(2006 a)\end{array}$ & $\begin{array}{l}\text { Tang } \\
(2006 a)\end{array}$ & & & & & & & & \\
\hline & Risk gap identification & $\begin{array}{l}\text { Colicchia } \\
\text { and } \\
\text { Strozzi } \\
(2012)\end{array}$ & $\begin{array}{l}\text { Colicchia } \\
\text { and } \\
\text { Strozzi } \\
(2012)\end{array}$ & $\begin{array}{l}\text { Colicchia } \\
\text { and } \\
\text { Strozzi } \\
(2012)\end{array}$ & $\begin{array}{l}\text { Colicchia } \\
\text { and } \\
\text { Strozzi } \\
(2012)\end{array}$ & $\begin{array}{l}\text { Colicchia } \\
\text { and } \\
\text { Strozzi } \\
(2012)\end{array}$ & $\begin{array}{l}\text { Colicchia } \\
\text { and } \\
\text { Strozzi } \\
(2012)\end{array}$ & $\begin{array}{l}\text { Colicchia } \\
\text { and } \\
\text { Strozzi } \\
(2012)\end{array}$ & $\begin{array}{l}\text { Colicchia } \\
\text { and } \\
\text { Strozzi } \\
(2012)\end{array}$ & & & \\
\hline \multirow{4}{*}{ : } & Risk classification & $\begin{array}{l}\text { Tang and } \\
\text { Musa } \\
\text { (2011) }\end{array}$ & $\begin{array}{l}\text { Tang and } \\
\text { Musa } \\
\text { (2011) }\end{array}$ & $\begin{array}{l}\text { Tang and } \\
\text { Musa } \\
\text { (2011) }\end{array}$ & $\begin{array}{l}\text { Tang and } \\
\text { Musa } \\
\text { (2011) }\end{array}$ & $\begin{array}{l}\text { Tang and } \\
\text { Musa } \\
\text { (2011) }\end{array}$ & $\begin{array}{l}\text { Tang and } \\
\text { Musa } \\
\text { (2011) }\end{array}$ & & & & & \\
\hline & Risk factor analysis & $\begin{array}{l}\text { Rao and } \\
\text { Goldsby } \\
\text { (2009) }\end{array}$ & $\begin{array}{l}\text { Rao and } \\
\text { Goldsby } \\
\text { (2009) }\end{array}$ & $\begin{array}{l}\text { Rao and } \\
\text { Goldsby } \\
\text { (2009) }\end{array}$ & $\begin{array}{l}\text { Rao and } \\
\text { Goldsby } \\
\text { (2009) }\end{array}$ & $\begin{array}{l}\text { Rao and } \\
\text { Goldsby } \\
\text { (2009) }\end{array}$ & $\begin{array}{l}\text { Rao and } \\
\text { Goldsby } \\
\text { (2009) }\end{array}$ & & & & & \\
\hline & Risk management methods & & & & & & & & & & & \\
\hline & Risk gap identification & $\begin{array}{l}\text { Colicchia } \\
\text { and } \\
\text { Strozzi } \\
(2012)\end{array}$ & $\begin{array}{l}\text { Colicchia } \\
\text { and } \\
\text { Strozzi } \\
(2012)\end{array}$ & $\begin{array}{l}\text { Colicchia } \\
\text { and } \\
\text { Strozzi } \\
(2012)\end{array}$ & $\begin{array}{l}\text { Colicchia } \\
\text { and } \\
\text { Strozzi } \\
(2012)\end{array}$ & $\begin{array}{l}\text { Colicchia } \\
\text { and } \\
\text { Strozzi } \\
(2012)\end{array}$ & $\begin{array}{l}\text { Colicchia } \\
\text { and } \\
\text { Strozzi } \\
(2012)\end{array}$ & $\begin{array}{l}\text { Colicchia } \\
\text { and } \\
\text { Strozzi } \\
(2012)\end{array}$ & $\begin{array}{l}\text { Colicchia } \\
\text { and } \\
\text { Strozzi } \\
(2012)\end{array}$ & & & \\
\hline
\end{tabular}


Table 2. Definitions of supply chain risk given by researchers.

\begin{tabular}{|l|l|l|}
\hline \multicolumn{1}{|c|}{ Authors } & \multicolumn{1}{|c|}{ Definitions of supply chain risk } & \multicolumn{1}{|c|}{ Scopes } \\
\hline Zsidisin (2003, p. 222) & $\begin{array}{l}\text { "The probability of an incident associated with } \\
\text { inbound supply from individual supplier failures or } \\
\text { the supply market occurring, in which its outcomes } \\
\text { result in the inability of the purchasing firm to meet } \\
\text { customer demand or cause threats to customer life } \\
\text { and safety." }\end{array}$ & Supply risk only \\
\hline $\begin{array}{l}\text { Jüttner et al. (2003, p. } \\
\text { 200) }\end{array}$ & $\begin{array}{l}\text { "Any risks for the information, material and product } \\
\text { flows from original suppliers to the delivery of the } \\
\text { final product for the end user.” }\end{array}$ & $\begin{array}{l}\text { Information, material, } \\
\text { and product flow risks }\end{array}$ \\
\hline $\begin{array}{l}\text { Wagner and Bode (2006, } \\
\text { p. 303) }\end{array}$ & $\begin{array}{l}\text { "The negative deviation from the expected value of a } \\
\text { certain performance measure, resulting in negative } \\
\text { consequences for the focal firm.” }\end{array}$ & General risks \\
\hline $\begin{array}{l}\text { Bogataj and Bogataj } \\
\text { (2007, p. 291) }\end{array}$ & $\begin{array}{l}\text { "The potential variation of outcomes that influence } \\
\text { the decrease of value added at any activity cell in a } \\
\text { chain.” }\end{array}$ & General risks \\
\hline Ellis et al. (2010, p. 36) & $\begin{array}{l}\text { “An individual's perception of the total potential loss } \\
\text { associated with the disruption of supply of a } \\
\text { particular purchased item from a particular supplier." }\end{array}$ & Supply risk only \\
\hline
\end{tabular}

Table 3. Definitions of SCRM given by researchers.

\begin{tabular}{|l|l|l|}
\hline \multicolumn{1}{|c|}{ Authors } & \multicolumn{1}{|c|}{ Definitions of SCRM } & \multicolumn{1}{c|}{ Scopes } \\
\hline $\begin{array}{l}\text { Jüttner et al. (2003, p. } \\
\text { 124) and Jüttner (2005, p. }\end{array}$ & $\begin{array}{l}\text { "The identification and management of risks for the } \\
\text { supply chain, through a co-ordinated approach } \\
\text { amongst supply chain members, to reduce supply } \\
\text { chain vulnerability as a whole." }\end{array}$ & $\begin{array}{l}\text { Identification and } \\
\text { management processes }\end{array}$ \\
\hline $\begin{array}{l}\text { Norrman and Jansson } \\
\text { (2004, p. 436) }\end{array}$ & $\begin{array}{l}\text { "To collaborate with partners in a supply chain apply } \\
\text { risk management process tools to deal with risks and } \\
\text { uncertainties caused by, or impacting on, logistics } \\
\text { related activities or resources." }\end{array}$ & Generic processes \\
\hline Tang (2006a, p. 453) & $\begin{array}{l}\text { "The management of supply chain risks through } \\
\text { coordination or collaboration among the supply chain } \\
\text { partners so as to ensure profitability and continuity." }\end{array}$ & Generic processes \\
\hline $\begin{array}{l}\text { Goh et al. (2007, p. 164- } \\
\text { 165) }\end{array}$ & $\begin{array}{l}\text { "The identification and management of risks within } \\
\text { the supply network and externally through a co- } \\
\text { ordinated approach amongst supply chain members } \\
\text { to reduce supply chain vulnerability as a whole." }\end{array}$ & $\begin{array}{l}\text { Identification and } \\
\text { management processes }\end{array}$ \\
\hline $\begin{array}{l}\text { Thun and Hoenig (2011, } \\
\text { p. 243) }\end{array}$ & $\begin{array}{l}\text { "Characterized by a cross-company orientation } \\
\text { aiming at the identification and reduction of risks not } \\
\text { only at the company level, but rather focusing on the } \\
\text { entire supply chain" }\end{array}$ & $\begin{array}{l}\text { Identification and } \\
\text { mitigation processes }\end{array}$ \\
\hline
\end{tabular}


Table 4. Supply chain risk types identified by researchers.

\begin{tabular}{|c|c|}
\hline Authors & Risk types \\
\hline Harland et al. (2003) & $\begin{array}{l}\text { Strategic, operations, supply, customer, asset impairment, competitive, reputation, financial, } \\
\text { fiscal, regulatory, and legal risks }\end{array}$ \\
\hline Jüttner et al. (2003) & $\begin{array}{l}\text { - Environmental risk } \\
\text { - Network-related risk } \\
\text { - Organizational risk }\end{array}$ \\
\hline Cavinato (2004) & Physical, financial, informational, relational, and innovational risks \\
\hline Chopra and Sodhi (2004) & $\begin{array}{l}\text { Disruptions, delays, systems, forecast, intellectual property, procurement, receivables, } \\
\text { inventory, and capacity risks }\end{array}$ \\
\hline $\begin{array}{l}\text { Christopher and Peck } \\
\text { (2004) }\end{array}$ & $\begin{array}{l}\text { - External to the network: environmental risk } \\
\text { - External to the firm but internal to the supply chain network: demand and supply risks } \\
\text { - Internal to the firm: process and control risks }\end{array}$ \\
\hline Tang (2006a) & $\begin{array}{l}\text { - Operational risks: uncertain customer demand, uncertain supply, and uncertain cost } \\
\text { - Disruption risks: earthquakes, floods, hurricanes, terrorist attacks, economics crises }\end{array}$ \\
\hline Wu et al. (2006) & $\begin{array}{l}\text { - Internal risks: internal controllable, internal partially controllable, internal uncontrollable } \\
\text { - External risks: external controllable, external partially controllable, external uncontrollable }\end{array}$ \\
\hline Bogataj and Bogataj (2007) & Supply, process (production or distribution), demand, control, and environmental risks \\
\hline Blackhurst et al. (2008) & $\begin{array}{l}\text { Disruptions/disasters, logistics, supplier dependence, quality, information systems, forecast, } \\
\text { legal, intellectual property, procurement, receivables (accounting), inventory, capacity, } \\
\text { management, and security risks }\end{array}$ \\
\hline Manuj and Mentzer (2008) & Supply, demand, operational, and other risks \\
\hline Tang and Tomlin (2008) & Supply, process, demand, intellectual property, behavioral, and political/social risks \\
\hline Wagner and Bode (2008) & Demand side, supply side, regulatory and legal, infrastructure risk, and catastrophic risks \\
\hline $\begin{array}{l}\text { Trkman and McCormack } \\
\text { (2009) }\end{array}$ & $\begin{array}{l}\text { - Endogenous risks: market and technology turbulence } \\
\text { - Exogenous risks: discrete events (e.g., terrorist attacks, contagious diseases, workers' } \\
\text { strikes) and continuous risks (e.g., inflation rate, consumer price index changes) }\end{array}$ \\
\hline Kumar et al. (2010) & $\begin{array}{l}\text { - Internal operational risks: demand, production and distribution, supply risks } \\
\text { - External operational risks: terrorist attacks, natural disasters, exchange rate fluctuations }\end{array}$ \\
\hline Olson and Wu (2010) & $\begin{array}{l}\text { - Internal risks: available capacity, internal operation, information system risks } \\
\text { - External risks: nature, political system, competitor and market risks }\end{array}$ \\
\hline Ravindran et al. (2010) & $\begin{array}{l}\text { - Value-at-risk (VaR): labor strike, terrorist attack, natural disaster } \\
\text { - Miss-the-target (MtT): late delivery, missing quality requirements }\end{array}$ \\
\hline Lin and Zhou (2011) & $\begin{array}{l}\text { - Risk in the external environment } \\
\text { - Risk within the supply chain } \\
\text { - Internal risk }\end{array}$ \\
\hline Tang and Musa (2011) & Material flow, financial flow, and information flow risks \\
\hline $\begin{array}{l}\text { Tummala and Schoenherr } \\
\text { (2011) }\end{array}$ & $\begin{array}{l}\text { Demand, delay, disruption, inventory, manufacturing (process) breakdown, physical plant } \\
\text { (capacity), supply (procurement), system, sovereign, and transportation risks }\end{array}$ \\
\hline Samvedi et al. (2013) & Supply, demand, process, and environmental risks \\
\hline
\end{tabular}


Table 5. Classification of supply chain risk factors identified by researchers into the conceptual framework.

\begin{tabular}{|c|c|c|c|c|c|c|c|}
\hline \multirow{2}{*}{ Authors } & \multirow[t]{2}{*}{ Macro factors } & \multicolumn{6}{|c|}{ Micro factors } \\
\hline & & Demand factors & Manufacturing factors & Supply factors & Information factors & Transportation factors & Financial factors \\
\hline $\begin{array}{l}\text { Zsidisin and } \\
\text { Ellram (2003) }\end{array}$ & & & & $\begin{array}{l}\text { Inability to handle volume } \\
\text { demand changes; failures to } \\
\text { make delivery } \\
\text { requirements; cannot } \\
\text { provide competitive pricing; } \\
\text { technologically behind } \\
\text { competitors; inability to } \\
\text { meet quality requirements }\end{array}$ & & & \\
\hline $\begin{array}{l}\text { Chopra and } \\
\text { Sodhi (2004) }\end{array}$ & $\begin{array}{l}\text { Natural disaster; } \\
\text { war and terrorism }\end{array}$ & $\begin{array}{l}\text { Inaccurate forecasts; } \\
\text { bullwhip effect or } \\
\text { information distortion; } \\
\text { demand uncertainty }\end{array}$ & $\begin{array}{l}\text { Labor dispute; rate of } \\
\text { product obsolescence; } \\
\text { inventory holding cost; } \\
\text { cost of capacity; capacity } \\
\text { flexibility }\end{array}$ & $\begin{array}{l}\text { Supplier bankruptcy; } \\
\text { Dependency on a single } \\
\text { source of supply; the } \\
\text { capacity and } \\
\text { responsiveness of } \\
\text { alternative suppliers; high } \\
\text { capacity utilization at } \\
\text { supply source; inflexibility } \\
\text { of supply source; poor } \\
\text { quality or yield at supply } \\
\text { source; global outsourcing; } \\
\text { percentage of a key } \\
\text { component or raw material } \\
\text { procured from a single } \\
\text { source; industrywide } \\
\text { capacity utilization; long- } \\
\text { versus short-term contracts; } \\
\text { supply uncertainty }\end{array}$ & $\begin{array}{l}\text { Information } \\
\text { infrastructure } \\
\text { breakdown; system } \\
\text { integration or } \\
\text { extensive systems } \\
\text { networking; } \\
\text { E-commerce }\end{array}$ & $\begin{array}{l}\text { Excessive handling } \\
\text { due to border } \\
\text { crossings or to change } \\
\text { in transportation } \\
\text { modes }\end{array}$ & $\begin{array}{l}\text { Exchange rate; } \\
\text { financial strength of } \\
\text { customers }\end{array}$ \\
\hline $\begin{array}{l}\text { Cucchiella and } \\
\text { Gastaldi (2006) }\end{array}$ & $\begin{array}{l}\text { Political } \\
\text { environment }\end{array}$ & Manufacturing yield & $\begin{array}{l}\text { Available capacity; } \\
\text { internal organization }\end{array}$ & Supplier quality & Information delays & & $\begin{array}{l}\text { Price fluctuations; } \\
\text { stochastic cost }\end{array}$ \\
\hline $\begin{array}{l}\text { Gaudenzi and } \\
\text { Borghesi } \\
\text { (2006) }\end{array}$ & & $\begin{array}{l}\text { Customer fragmentation; } \\
\text { high level of service } \\
\text { required by customers; } \\
\text { serious forecasting } \\
\text { errors; short lead times }\end{array}$ & $\begin{array}{l}\text { Short life time products; } \\
\text { linked phases in } \\
\text { manufacturing; stock } \\
\text { driven supply chain; } \\
\text { warehouse and production } \\
\text { disruption }\end{array}$ & $\begin{array}{l}\text { Narrow number of } \\
\text { intermediate suppliers; low } \\
\text { intermediate suppliers' } \\
\text { integration; lack of } \\
\text { integration with final- } \\
\text { product supplier; lack of } \\
\text { intermediate suppliers' } \\
\text { visibility; lack of final- } \\
\text { product suppliers' visibility }\end{array}$ & $\begin{array}{l}\text { Lack of information } \\
\text { transparency between } \\
\text { logistics and marketing }\end{array}$ & $\begin{array}{l}\text { Lack of outbound } \\
\text { effectiveness; transport } \\
\text { providers' } \\
\text { fragmentation; lack of } \\
\text { transport providers' } \\
\text { integration; damages } \\
\text { in transport; no } \\
\text { transport solution } \\
\text { alternatives }\end{array}$ & \\
\hline
\end{tabular}




\begin{tabular}{|c|c|c|c|c|c|c|c|}
\hline $\begin{array}{l}\text { Wu et al. } \\
\text { (2006) }\end{array}$ & $\begin{array}{l}\text { Fire accidents; } \\
\text { External legal } \\
\text { issues; } \\
\text { political/economic } \\
\text { stability }\end{array}$ & $\begin{array}{l}\text { Sudden shoot-up } \\
\text { demand; }\end{array}$ & $\begin{array}{l}\text { Quality; production } \\
\text { capabilities/capacity; } \\
\text { production flexibility; } \\
\text { technical/knowledge } \\
\text { resources; employee } \\
\text { accidents; labor strikes }\end{array}$ & $\begin{array}{l}\text { Supplier management; } \\
\text { supplier market strength; } \\
\text { continuity of supply; } \\
\text { second-tier supplier }\end{array}$ & Internet security & $\begin{array}{l}\text { On-time delivery; } \\
\text { accidents in } \\
\text { transportation; } \\
\text { maritime pirate attack; } \\
\text { remote high-way theft }\end{array}$ & $\begin{array}{l}\text { Cost; financial and } \\
\text { insurance issues; } \\
\text { loss of contract; low } \\
\text { profit margin; } \\
\text { market growth; } \\
\text { market size }\end{array}$ \\
\hline $\begin{array}{l}\text { Kull and Talluri } \\
\text { (2008) }\end{array}$ & & & & $\begin{array}{l}\text { Delivery failure; cost } \\
\text { failure; quality failure; } \\
\text { flexibility failure; general } \\
\text { confidence failure }\end{array}$ & & & \\
\hline $\begin{array}{l}\text { Manuj and } \\
\text { Mentzer (2008) }\end{array}$ & & $\begin{array}{l}\text { Demand variability; } \\
\text { forecast errors; } \\
\text { competitor moves }\end{array}$ & $\begin{array}{l}\text { Inventory ownership; } \\
\text { asset and tools ownership; } \\
\text { product quality and safety }\end{array}$ & $\begin{array}{l}\text { Supplier opportunism; } \\
\text { inbound product quality; } \\
\text { transit time variability }\end{array}$ & & & $\begin{array}{l}\text { Currency } \\
\text { fluctuations; wage } \\
\text { rate shifts }\end{array}$ \\
\hline $\begin{array}{l}\text { Schoenherr et } \\
\text { al. (2008) }\end{array}$ & $\begin{array}{l}\text { Sovereign risk; } \\
\text { natural } \\
\text { disasters/terrorists }\end{array}$ & & $\begin{array}{l}\text { ANSI compliance; } \\
\text { product quality; } \\
\text { engineering and } \\
\text { innovation }\end{array}$ & $\begin{array}{l}\text { Wrong partner; supplier’s } \\
\text { supplier management }\end{array}$ & & $\begin{array}{l}\text { On-time/on-budget } \\
\text { delivery }\end{array}$ & Product cost \\
\hline Tsai (2008) & & & & & & & $\begin{array}{l}\text { Lead time for } \\
\text { internal processing } \\
\text { and the timing of its } \\
\text { related cash } \\
\text { outflows; credit } \\
\text { periods for accounts } \\
\text { receivable to its } \\
\text { customers and the } \\
\text { pattern of early } \\
\text { collection of } \\
\text { accounts receivable; } \\
\text { credit periods for } \\
\text { accounts payable } \\
\text { from its suppliers } \\
\text { and the pattern of } \\
\text { early payment of } \\
\text { accounts payable }\end{array}$ \\
\hline $\begin{array}{l}\text { Tuncel and } \\
\text { Alpan (2010) }\end{array}$ & & $\begin{array}{l}\text { Deficient or missing } \\
\text { customer relation } \\
\text { management function; } \\
\text { high competition in the } \\
\text { marketplace }\end{array}$ & $\begin{array}{l}\text { Operator absence; strikes; } \\
\text { dissatisfaction with work; } \\
\text { insufficient maintenance; } \\
\text { instable manufacturing } \\
\text { process; loss of } \\
\text { motivation; lack of } \\
\text { experience or training; } \\
\text { insufficient breaks; } \\
\text { working conditions }\end{array}$ & $\begin{array}{l}\text { Monopoly; contractual } \\
\text { agreements; technological } \\
\text { changes; low technical } \\
\text { reliability }\end{array}$ & & $\begin{array}{l}\text { Stress on crew; lack of } \\
\text { training; long working } \\
\text { times; negligently } \\
\text { maintenance; old } \\
\text { technology; selected } \\
\text { delivery modes and } \\
\text { period }\end{array}$ & \\
\hline
\end{tabular}




\begin{tabular}{|c|c|c|c|c|c|c|c|}
\hline $\begin{array}{l}\text { Wagner and } \\
\text { Neshat (2010) }\end{array}$ & & $\begin{array}{l}\text { Short products' life } \\
\text { cycles; customers' } \\
\text { dependency; low in- } \\
\text { house production } \\
\end{array}$ & $\begin{array}{l}\text { Lean inventory; } \\
\text { centralized storage of } \\
\text { finished products }\end{array}$ & $\begin{array}{l}\text { Small supply base; } \\
\text { suppliers' dependency; } \\
\text { single sourcing }\end{array}$ & & $\begin{array}{l}\text { Global sourcing } \\
\text { network; supply chain } \\
\text { complexity }\end{array}$ & \\
\hline $\begin{array}{l}\text { Tummala and } \\
\text { Schoenherr } \\
\text { (2011) }\end{array}$ & $\begin{array}{l}\text { Natural disasters; } \\
\text { terrorism and } \\
\text { wars; regional } \\
\text { instability; } \\
\text { government } \\
\text { regulations }\end{array}$ & $\begin{array}{l}\text { Order fulfilment errors; } \\
\text { inaccurate forecasts; } \\
\text { information distortion; } \\
\text { demand uncertainty }\end{array}$ & $\begin{array}{l}\text { Labor disputes; costs of } \\
\text { holding inventories; rate } \\
\text { of product obsolescence; } \\
\text { poor quality; lower } \\
\text { process yields; higher } \\
\text { product cost; design } \\
\text { changes; lack of capacity } \\
\text { flexibility; cost of } \\
\text { capacity }\end{array}$ & $\begin{array}{l}\text { Single source of supply; } \\
\text { capacity and responsiveness } \\
\text { of alternative suppliers; } \\
\text { supply uncertainty; supplier } \\
\text { fulfilment; quality of } \\
\text { service, including } \\
\text { responsiveness and delivery } \\
\text { performance; supplier } \\
\text { fulfilment errors; selection } \\
\text { of wrong partners; high } \\
\text { capacity utilization at } \\
\text { supply source; inflexibility } \\
\text { of supply source; poor } \\
\text { quality or process yield at } \\
\text { supply source; supplier } \\
\text { bankruptcy; percentage of a } \\
\text { key component or raw } \\
\text { material procured from a } \\
\text { single source }\end{array}$ & $\begin{array}{l}\text { Information } \\
\text { infrastructure } \\
\text { breakdowns; lack of } \\
\text { effective system } \\
\text { integration or extensive } \\
\text { system networking; } \\
\text { lack of compatibility in } \\
\text { IT platforms among } \\
\text { supply chain partners }\end{array}$ & $\begin{array}{l}\text { Excessive handling } \\
\text { due to border crossings } \\
\text { or change in } \\
\text { transportation mode; } \\
\text { port capacity and } \\
\text { congestion; custom } \\
\text { clearances at ports; } \\
\text { transportation } \\
\text { breakdowns; } \\
\text { paperwork and } \\
\text { scheduling; port } \\
\text { strikes; late deliveries; } \\
\text { higher costs of } \\
\text { transportation; } \\
\text { dependency on } \\
\text { transportation mode } \\
\text { chosen }\end{array}$ & Rate of exchange \\
\hline $\begin{array}{l}\text { Hahn and Kuhn } \\
\text { (2012a) }\end{array}$ & & Demand uncertainty & $\begin{array}{l}\text { Resource breakdown; } \\
\text { quality issues }\end{array}$ & $\begin{array}{l}\text { Supply uncertainty; supplier } \\
\text { solvency }\end{array}$ & & & $\begin{array}{l}\text { Interest rate level; } \\
\text { exchange rates }\end{array}$ \\
\hline $\begin{array}{l}\text { Samvedi et al. } \\
\text { (2013) }\end{array}$ & $\begin{array}{l}\text { Terrorism; } \\
\text { political } \\
\text { instability; natural } \\
\text { disasters; } \\
\text { economic } \\
\text { downturns; social } \\
\text { and cultural } \\
\text { grievances } \\
\end{array}$ & $\begin{array}{l}\text { Sudden fluctuations; } \\
\text { market changes; } \\
\text { competition changes; } \\
\text { forecast errors }\end{array}$ & $\begin{array}{l}\text { Machine failure; labor } \\
\text { strike; quality problems; } \\
\text { technological change }\end{array}$ & $\begin{array}{l}\text { Outsourcing; supplier } \\
\text { insolvency; quality; sudden } \\
\text { hike in costs }\end{array}$ & & & \\
\hline
\end{tabular}


Table 6. Summary of supply chain risk factors.

\begin{tabular}{|c|c|c|c|c|c|c|}
\hline \multirow[t]{3}{*}{ Macro risk factors } & \multicolumn{6}{|c|}{ Micro risk factors } \\
\hline & \multirow[t]{2}{*}{ Demand risk factors } & \multirow[t]{2}{*}{ Manufacturing risk factors } & \multirow[t]{2}{*}{ Supply risk factors } & \multicolumn{3}{|c|}{ Infrastructural risk factors } \\
\hline & & & & Information risk factors & Transportation risk factors & Financial risk factors \\
\hline $\begin{array}{l}\text { - Natural disaster } \\
\text { - War and terrorism } \\
\text { - Fire accidents } \\
\text { - Political instability } \\
\text { - Economic } \\
\text { downturns } \\
\text { - External legal } \\
\text { issues } \\
\text { - Sovereign risk } \\
\text { - Regional } \\
\text { instability } \\
\text { - Government } \\
\text { regulations } \\
\text { - Social and cultural } \\
\text { grievances }\end{array}$ & $\begin{array}{l}\text { - Inaccurate demand } \\
\text { forecasts } \\
\text { - Serious forecasting } \\
\text { errors } \\
\text { - Bullwhip effect or } \\
\text { information distortion } \\
\text { - Demand uncertainty } \\
\text { - Sudden shoot-up } \\
\text { demand } \\
\text { - Demand variability } \\
\text { - Customer fragmentation } \\
\text { - High level of service } \\
\text { required by customers } \\
\text { - Customer dependency } \\
\text { - Deficient or missing } \\
\text { customer relation } \\
\text { management function } \\
\text { - Short lead times } \\
\text { - Short products' life } \\
\text { cycle } \\
\text { - Competitor moves } \\
\text { - Competition changes } \\
\text { - Market changes } \\
\text { - High competition in the } \\
\text { - Larket } \\
\text { - } \text { ow in-house } \\
\text { production } \\
\text { Order fulfilment errors }\end{array}$ & $\begin{array}{l}\text { - Labor disputes/strikes } \\
\text { - Employee accidents } \\
\text { - Operator absence } \\
\text { - Dissatisfaction with work } \\
\text { - Lack of experience or } \\
\text { training } \\
\text { - Insufficient breaks } \\
\text { - Working conditions } \\
\text { - Product obsolescence } \\
\text { - Inventory holding cost } \\
\text { - Stock driven supply chain } \\
\text { - Inventory ownership } \\
\text { - Lean inventory } \\
\text { - Production flexibility } \\
\text { - Production } \\
\text { capabilities/capacity } \\
\text { - Products quality and } \\
\text { - Tafety } \\
\text { - Technical/knowledge } \\
\text { - Enguinees } \\
\text { innovation and } \\
\text { - Shorter life time products } \\
\text { - Linked phases in } \\
\text { manufacturing } \\
\text { - Warehouse and production } \\
\text { disruption } \\
\text { - Insufficient maintenance } \\
\text { - Instable manufacturing } \\
\text { process } \\
\text { - Centralized storage of } \\
\text { - Desinished products } \\
\text { - Technological change }\end{array}$ & $\begin{array}{l}\text { - Inability to handle volume } \\
\text { - } \text { demand changes } \\
\text { requilures to make delivery } \\
\text { - Cannot provide } \\
\text { competitive pricing } \\
\text { - Technologically behind } \\
\text { competitors } \\
\text { - Inability to meet quality } \\
\text { requirements } \\
\text { - Supplier bankruptcy } \\
\text { - Single supply sourcing } \\
\text { - Small supply base } \\
\text { - Suppliers' dependency } \\
\text { - Supply responsiveness } \\
\text { - High capacity utilization } \\
\text { ay supply source } \\
\text { - Global outsourcing } \\
\text { - Narrow number of } \\
\text { intermediate suppliers } \\
\text { - Lack of integration with } \\
\text { - suppliers } \\
\text { - Lack of suppliers' } \\
\text { visibility } \\
\text { - Supplier management } \\
\text { - Supplier market strength } \\
\text { - Supplier opportunism } \\
\text { - Monopoly } \\
\text { - Selection of wrong partner } \\
\text { - Transit time variability } \\
\text { - Contractual agreements } \\
\text { - Low technical reliability } \\
\text { - Supplier fulfilment errors } \\
\text { - Sudden hike in costs }\end{array}$ & $\begin{array}{l}\text { - Information infrastructure } \\
\text { breakdown } \\
\text { - System integration or } \\
\text { extensive systems } \\
\text { networking } \\
\text { - E-commerce } \\
\text { - Information delays } \\
\text { - Lack of information } \\
\text { transparency between } \\
\text { logistics and marketing } \\
\text { - Internet security } \\
\text { - Lack of compatibility in IT } \\
\text { platforms among supply } \\
\text { chain partners }\end{array}$ & $\begin{array}{l}\text { - Excessive handling due to } \\
\text { border crossings or change } \\
\text { in transportation modes } \\
\text { - Lack of outbound } \\
\text { effectiveness } \\
\text { - Transport providers' } \\
\text { fragmentation } \\
\text { - No transport solution } \\
\text { alternatives } \\
\text { - On-time/on-budget } \\
\text { delivery } \\
\text { - Damages in transport } \\
\text { - Accidents in transportation } \\
\text { - Maritime pirate attack } \\
\text { - Remote high-way theft } \\
\text { - Stress on crew } \\
\text { - Lack of training } \\
\text { - Long working times } \\
\text { - Negligently maintenance } \\
\text { - Old technology } \\
\text { - Transportation breakdowns } \\
\text { - Port strikes } \\
\text { - Global sourcing network } \\
\text { - Supply chain complexity } \\
\text { - Port capacity and } \\
\text { congestion } \\
\text { - Custom clearances at ports } \\
\text { - Paperwork and scheduling } \\
\text { - Higher costs of } \\
\text { transportation }\end{array}$ & $\begin{array}{l}\text { - Exchange rate } \\
\text { - } \text { Currency fluctuations } \\
\text { - Interest rate level } \\
\text { - Wage rate shifts } \\
\text { - Financial strength of } \\
\text { customers } \\
\text { - Price fluctuations } \\
\text { - Product cost } \\
\text { - Financial and insurance } \\
\text { issues } \\
\text { - Loss of contract } \\
\text { - Low profit margin } \\
\text { - Market growth } \\
\text { - Market size } \\
\text { - Lead time for internal } \\
\text { processing and the timing } \\
\text { of its related cash outflows } \\
\text { - Credit periods for accounts } \\
\text { receivable to its customers } \\
\text { and the pattern of early } \\
\text { collection of accounts } \\
\text { receivable } \\
\text { - Credit periods for accounts } \\
\text { payable from its suppliers } \\
\text { and the pattern of early } \\
\text { payment of accounts } \\
\text { payable }\end{array}$ \\
\hline
\end{tabular}


Table 7. Summary of individual quantitative methods.

\begin{tabular}{|c|c|c|}
\hline Methods & $\begin{array}{l}\text { No. of } \\
\text { articles }\end{array}$ & Authors \\
\hline 1. Analytical methods & 112 & \\
\hline Mathematical programming & 47 & \\
\hline $\begin{array}{l}\text { - Unconstrained and constrained mathematical } \\
\text { programming }\end{array}$ & 9 & $\begin{array}{l}\text { Tomlin (2006), Chopra et al. (2007), He and Zhang } \\
\text { (2008), Tang and Tomlin (2008), Chen and Yano } \\
\text { (2010), Iakovou et al. (2010), Wang et al. (2011), } \\
\text { Gümüş et al. (2012), Xanthopoulos et al. (2012) }\end{array}$ \\
\hline - $\quad$ Linear programming & 5 & $\begin{array}{l}\text { Kaya and Özer (2009), Meena et al. (2011), Schmitt } \\
\text { (2011), Qiang and Nagurney (2012), Radke and Tseng } \\
\text { (2012) }\end{array}$ \\
\hline • Nonlinear programming & 5 & $\begin{array}{l}\text { Cruz et al. (2006), Cruz (2009), Raghavan and Mishra } \\
\text { (2011), Kang and Kim (2012), Kim et al. (2012) }\end{array}$ \\
\hline • Integer nonlinear programming & 4 & $\begin{array}{l}\text { Baghalian et al. (2013), Hishamuddin et al. (2013), } \\
\text { Kumar and Tiwari (2013), Meena and Sarmah (2013) }\end{array}$ \\
\hline - Stochastic linear programming & 4 & $\begin{array}{l}\text { Sodhi (2005), Keren (2009), Sodhi and Tang (2009), } \\
\text { Mak and Shen (2012) }\end{array}$ \\
\hline - Stochastic integer linear programming & 3 & Snyder et al. (2007), Lejeune (2008), Sawik (2013a) \\
\hline - Max-mix linear programming & 2 & Talluri and Narasimhan (2003), Yang et al. (2009) \\
\hline - Mixed integer linear programming & 2 & Georgiadis et al. (2011), Sawik (2013b) \\
\hline - Multi-objective mixed integer linear programming & 2 & Ravindran et al. (2010), Wakolbinger and Cruz (2011) \\
\hline - Multi-stage stochastic programming & 2 & Goh et al. (2007), Shi et al. (2011) \\
\hline - Two-stage stochastic integer programming & 2 & Poojari et al. (2008), Hahn and Kuhn (2012b) \\
\hline - Convex mixed integer programming & 1 & Azad and Davoudpour (2013) \\
\hline - Integer linear programming & 1 & Hale and Moberg (2005) \\
\hline - Multi-objective stochastic programming & 1 & Azaron et al. (2008) \\
\hline - Multi-period deterministic linear programming & 1 & Ben-Tal et al. (2011) \\
\hline - Parametric linear programming & 1 & Bogataj and Bogataj (2007) \\
\hline - Quadratic programming & 1 & Talluri et al. (2010) \\
\hline - Stochastic dynamic programming & 1 & Kenné et al. (2012) \\
\hline Newsvendor model & 10 & $\begin{array}{l}\text { Cachon (2004), Rao et al. (2005), Chen et al. (2006), Li } \\
\text { (2007), Tomlin (2009), Giri (2011), Xia et al. (2011), } \\
\text { Arcelus et al. (2012), Tang et al. (2012), Cheong and } \\
\text { Song (2013) }\end{array}$ \\
\hline Simulation & 10 & $\begin{array}{l}\text { Smaros et al. (2003), Crnkovic et al. (2008), Kull and } \\
\text { Closs (2008), Colicchia et al. (2010), Durowoju et al. } \\
\text { (2012), Schmitt and Singh (2012), Berle et al. (2013), } \\
\text { Glock and Ries (2013), Kim (2013), Son and Orchard } \\
\text { (2013) }\end{array}$ \\
\hline Analytic hierarchy process & 3 & $\begin{array}{l}\text { Wu et al. (2006), Gaudenzi and Borghesi (2006), } \\
\text { Schoenherr et al. (2008) }\end{array}$ \\
\hline Game theory & 3 & $\begin{array}{l}\text { Xiao and Yang (2008), Xiao and Yang (2009), Li et al. } \\
\text { (2010) }\end{array}$ \\
\hline Decision tree approach & 2 & $\begin{array}{l}\text { Berger et al. (2004), Ruiz-Torres and Mahmoodi } \\
(2007)\end{array}$ \\
\hline Interpretive structural modelling & 2 & Faisal et al. (2006), Diabat et al. (2012) \\
\hline Variational inequality model & 2 & Liu and Nagurney (2011), Cruz (2013) \\
\hline Analytic network process & 1 & Xia and Chen (2011) \\
\hline $\begin{array}{l}\text { Automatic pipeline inventory and order based } \\
\text { production control system algorithm }\end{array}$ & 1 & Towill (2005) \\
\hline Association rule hiding algorithm & 1 & Le et al. (2013) \\
\hline Approximate dynamic programming algorithm & 1 & Fang et al. (2013) \\
\hline Bayesian networks & 1 & Lockamy III and McCormack (2010) \\
\hline Buyer's risk adjustment quantity discount model & 1 & Shin and Benton (2007) \\
\hline Cash conversion cycle & 1 & Tsai (2008) \\
\hline
\end{tabular}




\begin{tabular}{|c|c|c|}
\hline $\begin{array}{l}\text { Comparisons of chance-constrained programming, data } \\
\text { envelopment analysis, and multi-objective programming } \\
\text { models }\end{array}$ & 1 & Wu and Olson (2008) \\
\hline Constrained multi-item $(\mathrm{Q}, \mathrm{r})$ inventory model & 1 & Betts and Johnston (2005) \\
\hline Disruption analysis network approach & 1 & Wu et al. (2007) \\
\hline Dynamic system model & 1 & Huang et al. (2009) \\
\hline Expected profit functions & 1 & Yu et al. (2009) \\
\hline Fault tree approach & 1 & Cigolini and Rossi (2010) \\
\hline Federated databases & 1 & Du et al. (2003) \\
\hline Harsanyi-Selten-Nash bargaining framework & 1 & Bakshi and Kleindorfer (2009) \\
\hline Hybrid Petri-net & 1 & Khilwani et al. (2011) \\
\hline Margin incremental analysis & 1 & Tse and Tan (2011) \\
\hline Macro prediction market model & 1 & Guo et al. (2006) \\
\hline Mean-variance analysis & 1 & Chiu et al. (2011) \\
\hline Multi-criteria scoring models & 1 & Blackhurst et al. (2008), \\
\hline Multi Kanban system for disassembly & 1 & Nakashima and Gupta (2012) \\
\hline Network flow modelling & 1 & Lundin (2012) \\
\hline Pugh method adaption & 1 & Dietrich and Cudney (2011) \\
\hline Principal-agent model & 1 & Lei et al. (2012) \\
\hline P-chart solution model & 1 & Sun et al. (2012) \\
\hline Random yield model & 1 & He (2013) \\
\hline Safety stock evaluation method & 1 & Talluri et al. (2004) \\
\hline Single stochastic period approximation & 1 & Schmitt et al. (2010) \\
\hline $\begin{array}{l}\text { Specifying sources of risk vulnerabilities, assessment and } \\
\text { mitigation framework }\end{array}$ & 1 & Kleindorfer and Saad (2005) \\
\hline Stochastic economic order quantity model & 1 & Ballou and Burnetas (2003) \\
\hline $\begin{array}{l}\text { Supply network opportunity assessment package } \\
\text { methodology }\end{array}$ & 1 & Brun et al. (2006) \\
\hline Supply chain resilience assessment and management & 1 & Pettit et al. (2013) \\
\hline Two-period financial modelling & 1 & Aggarwal and Ganeshan (2007) \\
\hline 2. Empirical methods & 7 & \\
\hline Multiple regression model & 3 & $\begin{array}{l}\text { Hung and Ryu (2008), Laeequddin et al. (2009), } \\
\text { Skipper and Hanna (2009) }\end{array}$ \\
\hline Partial least squares analysis & 1 & Kern et al. (2012) \\
\hline Quantitative survey analysis & 1 & Speier et al. (2011) \\
\hline Real options theory & 1 & Hult et al. (2010) \\
\hline Statistical analysis & 1 & Lavastre et al. (2012) \\
\hline Total & 119 & \\
\hline
\end{tabular}


Table 8. Summary of integrated quantitative methods.

\begin{tabular}{|c|c|c|}
\hline Methods & $\begin{array}{l}\text { No. of } \\
\text { articles }\end{array}$ & Authors \\
\hline 1. Analytical methods & 36 & \\
\hline Fuzzy set theory; Multi-objective mathematical programming & 3 & $\begin{array}{l}\text { Kumar et al. (2006), Wu et al. } \\
\text { (2010), Ji and Zhu (2012) }\end{array}$ \\
\hline Analytic hierarchy process; Fuzzy set theory & 2 & $\begin{array}{l}\text { Chan and Kumar (2007), Wang et } \\
\text { al. (2012) }\end{array}$ \\
\hline $\begin{array}{l}\text { Fuzzy analytic hierarchy process; Fuzzy technique for order preference by } \\
\text { similarity to the ideal solution }\end{array}$ & 2 & $\begin{array}{l}\text { Samvedi et al. (2013), } \\
\text { Viswanadham and Samvedi } \\
\text { (2013) }\end{array}$ \\
\hline Analytic hierarchy process; Goal programming & 1 & Kull and Talluri (2008) \\
\hline Analytic hierarchy process; Quality function deployment & 1 & Ho et al. (2011) \\
\hline Analytic hierarchy process; A modified failure mode and effect analysis & 1 & Chen and Wu (2013) \\
\hline $\begin{array}{l}\text { Analytic network process; Fuzzy goal programming; Five forces analysis; } \\
\text { Value-at-risk }\end{array}$ & 1 & Hung (2011) \\
\hline $\begin{array}{l}\text { Artificial bee colony technique; Genetic algorithms; Particle swarm } \\
\text { optimization }\end{array}$ & 1 & Kumar et al. (2010) \\
\hline Chance-constrained data envelopment analysis; Non-linear programming & 1 & Talluri et al. (2006) \\
\hline $\begin{array}{l}\text { Data envelopment analysis; Fuzzy data envelopment analysis; Chance- } \\
\text { constrained data envelopment analysis; Monte Carlo simulation }\end{array}$ & 1 & Azadeh and Alem (2010) \\
\hline Data envelopment analysis; Monte Carlo simulation & 1 & Olson and $\mathrm{Wu}(2011)$ \\
\hline Data envelopment analysis; Value-at-risk & 1 & Wu and Olson (2010) \\
\hline Data envelopment analysis; Simulation; Nonparametric statistical methods & 1 & Talluri et al. (2013) \\
\hline Decision tree approach; Mathematical programming & 1 & Ruiz-Torres et al. (2013) \\
\hline Extended dynamic demand forecast and inventory model & 1 & Reiner and Fichtinger (2009) \\
\hline Economic Value Added; Stochastic programming & 1 & Hahn and Kuhn (2012a) \\
\hline Failure mode, effects and criticality analysis technique; Petri-nets & 1 & Tuncel and Alpan (2010) \\
\hline Failure mode and effect analysis; Quality function deployment & 1 & Pujawan and Geraldin (2009) \\
\hline Forecasting and statistical techniques & 1 & Sucky (2009) \\
\hline Fuzzy set theory; Radial base function neural network & 1 & Zhang et al. (2011) \\
\hline Fuzzy set theory; Multi-criteria decision making & 1 & Haleh and Hamidi (2011) \\
\hline Fuzzy set theory; Stochastic multi-objective programming & 1 & Wu et al. (2013) \\
\hline $\begin{array}{l}\text { Fuzzy set theory; Failure mode and effect analysis; Ordered weighted } \\
\text { averaging }\end{array}$ & 1 & Chaudhuri et al. (2013) \\
\hline $\begin{array}{l}\text { Generalized Autoregressive Conditional Heteroskedasticity; Vector Auto } \\
\text { Regression }\end{array}$ & 1 & Datta et al. (2007) \\
\hline Genetic algorithm; Statistical methods & 1 & Sayed et al. (2009) \\
\hline Graph theory; Supply chain vulnerability index & 1 & Wagner and Neshat (2010) \\
\hline Lagrangian relaxation; Integer nonlinear programming model & 1 & Park et al. (2010) \\
\hline Monte Carlo simulation; Real options approach; Sensitivity analysis & 1 & Costantino and Pellegrino (2010) \\
\hline Multi-objective optimization; Six Sigma & 1 & Franca et al. (2010) \\
\hline Neyman-Pearson theory; Statistical quality control & 1 & Tapiero (2007) \\
\hline Supply chain risk structure model; Supply chain risk dynamics model & 1 & Oehmen et al. (2009) \\
\hline $\begin{array}{l}\text { Variational inequality model; Capital asset pricing model; Net present } \\
\text { value }\end{array}$ & 1 & Liu and Cruz (2012) \\
\hline 2. Empirical methods & 4 & \\
\hline $\begin{array}{l}\text { Analytic hierarchy process; Survey; Wards' and K-mean clustering; } \\
\text { Nonparametric Spearman rank correlation test }\end{array}$ & 1 & Tsai et al. (2008) \\
\hline Cluster analysis; Factor analysis & 1 & Hallikas et al. (2005) \\
\hline Exploratory factor analysis; Regression models; Reliability tests & 1 & Zsidisin and Ellram (2003) \\
\hline Structural equation modelling technique; Partial least squares analysis & 1 & Braunscheidel and Suresh (2009) \\
\hline Total & 40 & \\
\hline
\end{tabular}


Table 9. Distribution of number of quantitative and qualitative methods over the individual and integrated SCRM processes.

\begin{tabular}{|c|c|c|c|c|c|}
\hline \multicolumn{2}{|c|}{ SCRM processes } & \multicolumn{2}{|c|}{ Qualitative methods } & \multicolumn{2}{|c|}{ Quantitative methods } \\
\hline \multirow[t]{8}{*}{$\begin{array}{l}\text { Individual } \\
\text { process }\end{array}$} & \multirow[t]{2}{*}{ Identification } & \multicolumn{2}{|c|}{$\begin{array}{l}\text { Adhitya et al. (2009), Blos et al. (2009), Neiger et al. (2009), Trkman } \\
\text { and McCormack (2009), Kayis and Karningsih (2012) }\end{array}$} & \multicolumn{2}{|c|}{$\begin{array}{l}\text { Analytical: Gaudenzi and Borghesi (2006) } \\
\text { Empirical: Tsai et al. (2008) }\end{array}$} \\
\hline & & Number: 5 & Percentage: $2.40 \%$ & Number: 2 & Percentage: $0.96 \%$ \\
\hline & \multirow[t]{2}{*}{ Assessment } & \multicolumn{2}{|c|}{$\begin{array}{l}\text { Zsidisin et al. (2004), Craighead et al. (2007), Ellegaard (2008), Jüttner } \\
\text { and Maklan (2011), Johnson et al. (2013), Wiengarten et al. (2013) }\end{array}$} & \multicolumn{2}{|c|}{ 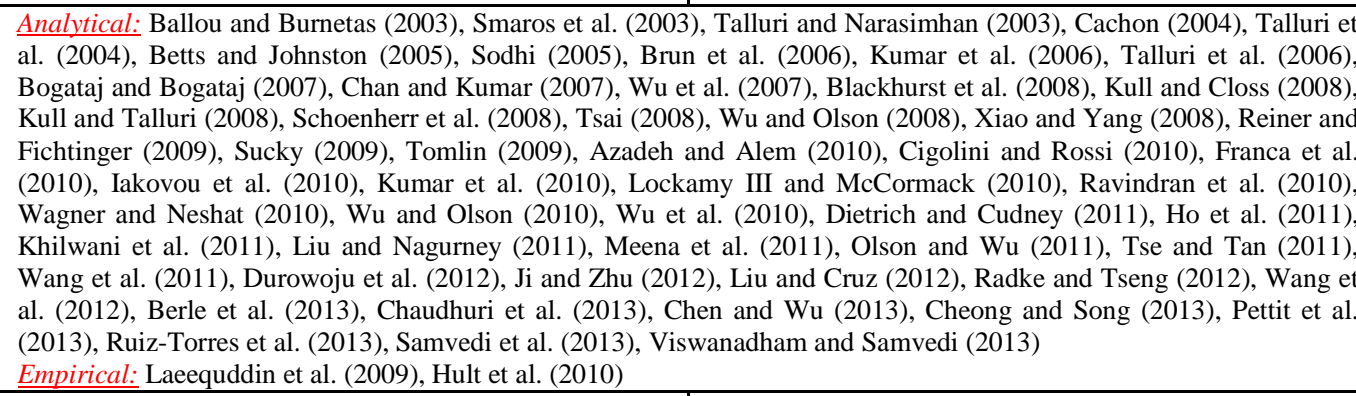 } \\
\hline & & Number: 6 & Percentage: $\mathbf{2 . 8 8 \%}$ & Number: 56 & Percentage: $26.92 \%$ \\
\hline & \multirow[t]{2}{*}{ Mitigation } & \multicolumn{2}{|c|}{$\begin{array}{l}\text { Christopher and Lee (2004), Giunipero and Eltantawy (2004), Zsidisin } \\
\text { and Smith (2005), Zsidisin et al. (2005), Choi and Krause (2006), Tang } \\
\text { (2006b), Khan et al. (2008), Manuj and Mentzer (2008), Dowty and } \\
\text { Wallace (2010), Yang and Yang (2010), Christopher et al. (2011), } \\
\text { Hofmann (2011), Wagner and Silveira-Camargos (2012), Chen et al. } \\
\text { (2013), Grötsch et al. (2013), Leat and Revoredo-Giha (2013), Vedel } \\
\text { and Ellegaard (2013) }\end{array}$} & \multicolumn{2}{|c|}{ 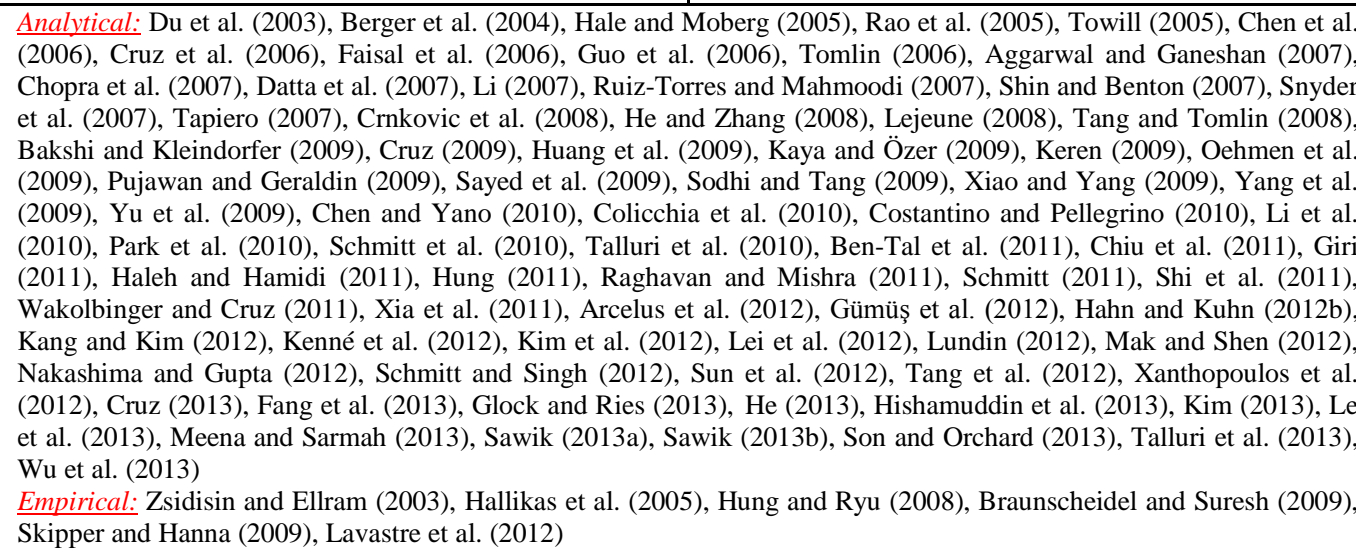 } \\
\hline & & Number: 17 & Percentage: $\mathbf{8 . 1 7 \%}$ & Number: 84 & Percentage: $\mathbf{4 0 . 3 8 \%}$ \\
\hline & \multirow[t]{2}{*}{ Monitoring } & & & \multicolumn{2}{|c|}{ Analytical: Zhang et al. (2011) } \\
\hline & & Number: 0 & \begin{tabular}{|l|l} 
Percentage: 0 \\
\end{tabular} & Number: 1 & Percentage: $0.48 \%$ \\
\hline \multirow{2}{*}{\multicolumn{2}{|c|}{ Integrated processes }} & \multicolumn{2}{|c|}{$\begin{array}{l}\text { Harland et al. (2003), Chopra and Sodhi (2004), Christopher and Peck } \\
\text { (2004), Hallikas et al. (2004), Norrman and Jansson (2004), Sinha et al. } \\
\text { (2004), Peck (2005), Cucchiella and Gastaldi (2006), Ritchie and } \\
\text { Brindley (2007), Smith et al. (2007), Cheng and Kam (2008), Wagner } \\
\text { and Bode (2008), Knemeyer et al. (2009), Oke and Gopalakrishnan } \\
\text { (2009), Foerstl et al. (2010), Blome and Schoenherr (2011), Giannakis } \\
\text { and Louis (2011), Tummala and Schoenherr (2011), Bandaly et al. } \\
\text { (2012), Ghadge et al. (2013), Kumar and Havey (2013) }\end{array}$} & \multicolumn{2}{|c|}{$\begin{array}{l}\text { Analytical: Kleindorfer and Saad (2005), Wu et al. (2006), Goh et al. (2007), Azaron et al. (2008), Poojari et al. (2008), } \\
\text { Tuncel and Alpan (2010), Georgiadis et al. (2011), Xia and Chen (2011), Diabat et al. (2012), Hahn and Kuhn (2012a), } \\
\text { Qiang and Nagurney (2012), Azad and Davoudpour (2013), Baghalian et al. (2013), Kumar and Tiwari (2013) } \\
\text { Empirical: Speier et al. (2011), Kern et al. (2012) }\end{array}$} \\
\hline & & Number: 21 & \begin{tabular}{|l|} 
Percentage: $\mathbf{1 0 . 1 0} \%$ \\
\end{tabular} & Number: 16 & Percentage: $7.69 \%$ \\
\hline Total & & Number: 49 & Percentage: $23.56 \%$ & Number: 159 & Percentage: $\mathbf{7 6 . 4 4 \%}$ \\
\hline
\end{tabular}


Table 10. Summary of risk types studied by the quantitative and qualitative SCRM methods.

\begin{tabular}{|c|c|c|}
\hline Risk types & $\begin{array}{c}\text { No. of } \\
\text { articles }\end{array}$ & References \\
\hline Supply risk & 70 & $\begin{array}{l}\text { Talluri and Narasimhan (2003), Zsidisin and Ellram (2003), Berger et al. (2004), Giunipero and Eltantawy (2004), Zsidisin et al. (2004), Hallikas et } \\
\text { al. (2005), Zsidisin and Smith (2005), Zsidisin et al. (2005), Choi and Krause (2006), Kumar et al. (2006), Talluri et al. (2006), Tomlin (2006), Wu et } \\
\text { al. (2006), Chan and Kumar (2007), Chopra et al. (2007), Ruiz-Torres and Mahmoodi (2007), Tapiero (2007), Blackhurst et al. (2008), Ellegaard } \\
\text { (2008), Kull and Closs (2008), Kull and Talluri (2008), Schoenherr et al. (2008), Wu and Olson (2008), Keren (2009), Trkman and McCormack } \\
\text { (2009), Yang et al. (2009), Yu et al. (2009), Azadeh and Alem (2010), Colicchia et al. (2010), Costantino and Pellegrino (2010), Foerstl et al. (2010), } \\
\text { Iakovou et al. (2010), Li et al. (2010), Lockamy III and McCormack (2010), Ravindran et al. (2010), Schmitt et al. (2010), Talluri et al. (2010), Wu et } \\
\text { al. (2010), Wu and Olson (2010), Blome and Schoenherr (2011), Christopher et al. (2011), Giri (2011), Haleh and Hamidi (2011), Ho et al. (2011), } \\
\text { Meena et al. (2011), Schmitt (2011), Shi et al. (2011), Wakolbinger and Cruz (2011), Gümüş et al. (2012), Kern et al. (2012), Kim et al. (2012), Mak } \\
\text { and Shen (2012), Xanthopoulos et al. (2012), Baghalian et al. (2013), Chaudhuri et al. (2013), Chen and Wu (2013), Cheong and Song (2013), Fang } \\
\text { et al. (2013), Grötsch et al. (2013), Glock and Ries (2013), Johnson et al. (2013), Meena and Sarmah (2013), Ruiz-Torres et al. (2013), Sawik } \\
\text { (2013a), Sawik (2013b), Son and Orchard (2013), Vedel and Ellegaard (2013), Viswanadham and Samvedi (2013), Wiengarten et al. (2013), Wu et } \\
\text { al. (2013) }\end{array}$ \\
\hline Demand risk & 39 & $\begin{array}{l}\text { Ballou and Burnetas (2003), Smaros et al. (2003), Cachon (2004), Talluri et al. (2004), Betts and Johnston (2005), Rao et al. (2005), Sodhi (2005), } \\
\text { Towill (2005), Chen et al. (2006), Guo et al. (2006), Aggarwal and Ganeshan (2007), Datta et al. (2007), Goh et al. (2007), Shin and Benton (2007), } \\
\text { Snyder et al. (2007), Crnkovic et al. (2008), Hung and Ryu (2008), Lejeune (2008), Poojari et al. (2008), Xiao and Yang (2008), Huang et al. (2009), } \\
\text { Reiner and Fichtinger (2009), Sayed et al. (2009), Sodhi and Tang (2009), Sucky (2009), Xiao and Yang (2009), Chen and Yano (2010), Park et al. } \\
\text { (2010), Ben-Tal et al. (2011), Georgiadis et al. (2011), Arcelus et al. (2012), Kang and Kim (2012), Lei et al. (2012), Qiang and Nagurney (2012), } \\
\text { Radke and Tseng (2012), Schmitt and Singh (2012), Tang et al. (2012), Baghalian et al. (2013), Kim (2013) }\end{array}$ \\
\hline Manufacturing risk & 13 & $\begin{array}{l}\text { Li (2007), He and Zhang (2008), Khan et al. (2008), Kaya and Özer (2009), Cigolini and Rossi (2010), Dietrich and Cudney (2011), Hung (2011), } \\
\text { Tse and Tan (2011), Zhang et al. (2011), Kenné et al. (2012), Qiang and Nagurney (2012), Sun et al. (2012), Kumar and Tiwari (2013) }\end{array}$ \\
\hline Financial risk & 10 & $\begin{array}{l}\text { Goh et al. (2007), Azaron et al. (2008), Tsai (2008), Franca et al. (2010), Hofmann (2011), Liu and Nagurney (2011), Raghavan and Mishra (2011), } \\
\text { Liu and Cruz (2012), Lundin (2012), Azad and Davoudpour (2013) }\end{array}$ \\
\hline Macro risk & 6 & 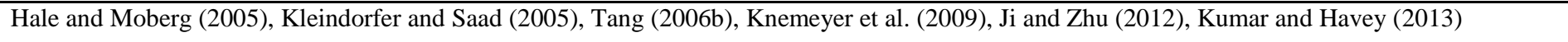 \\
\hline Information risk & 4 & Du et al. (2003), Smith et al. (2007), Durowoju et al. (2012), Le et al. (2013) \\
\hline Transportation risk & 1 & Hishamuddin et al. (2013) \\
\hline
\end{tabular}


Table 11. Summary of industries studied by the quantitative and qualitative SCRM methods.

\begin{tabular}{|c|c|c|}
\hline Application areas & $\begin{array}{l}\text { No. of } \\
\text { articles }\end{array}$ & References \\
\hline Automotive & 15 & $\begin{array}{l}\text { Kumar et al. (2006), Blackhurst et al. (2008), Kull and Talluri (2008), Wagner and Bode (2008), Blos et al. (2009), Trkman and McCormack } \\
\text { (2009), Lockamy III and McCormack (2010), Wagner and Neshat (2010), Blome and Schoenherr (2011), Ho et al. (2011), Hofmann (2011), } \\
\text { Kern et al. (2012), Sun et al. (2012), Wagner and Silveira-Camargos (2012), Grötsch et al. (2013) }\end{array}$ \\
\hline Electronics & 12 & $\begin{array}{l}\text { Harland et al. (2003), Zsidisin et al. (2004), Sodhi (2005), Zsidisin et al. (2005), Wagner and Bode (2008), Blos et al. (2009), Huang et al. } \\
\text { (2009), Blome and Schoenherr (2011), Christopher et al. (2011), Kern et al. (2012), Kim et al. (2012), Chen and Wu (2013) }\end{array}$ \\
\hline Aerospace & 9 & $\begin{array}{l}\text { Sinha et al. (2004), Zsidisin et al. (2004), Zsidisin and Smith (2005), Zsidisin et al. (2005), Wagner and Bode (2008), Christopher et al. (2011), } \\
\text { Dietrich and Cudney (2011), Kern et al. (2012), Chaudhuri et al. (2013) }\end{array}$ \\
\hline Fashion & 6 & Brun et al. (2006), Khan et al. (2008), Blome and Schoenherr (2011), Christopher et al. (2011), Wang et al. (2012), Vedel and Ellegaard (2013) \\
\hline Food & 6 & $\begin{array}{l}\text { Wagner and Bode (2008), Laeequddin et al. (2009), Dowty and Wallace (2010), Christopher et al. (2011), Zhang et al. (2011), Diabat et al. } \\
\text { (2012) }\end{array}$ \\
\hline Pharmaceutical & 6 & $\begin{array}{l}\text { Talluri and Narasimhan (2003), Talluri et al. (2004), Gaudenzi and Borghesi (2006), Talluri et al. (2006), Wagner and Bode (2008), Kern et al. } \\
\text { (2012) }\end{array}$ \\
\hline IT & 5 & Zsidisin et al. (2004), Wu et al. (2006), Smith et al. (2007), Wagner and Bode (2008), Ravindran et al. (2010) \\
\hline Agricultural & 4 & Ritchie and Brindley (2007), Pujawan and Geraldin (2009), Baghalian et al. (2013), Leat and Revoredo-Giha (2013) \\
\hline Chemical & 4 & Kleindorfer and Saad (2005), Wagner and Bode (2008), Foerstl et al. (2010), Kern et al. (2012) \\
\hline Energy & 4 & $\begin{array}{l}\text { Adhitya et al. (2009), Cigolini and Rossi (2010), Blome and Schoenherr (2011), Kern et al. (2012) } \\
\end{array}$ \\
\hline Telecommunications & 4 & Norrman and Jansson (2004), Zsidisin et al. (2004), Wagner and Neshat (2010), Hung (2011) \\
\hline Logistics & 3 & Wagner and Bode (2008), Blome and Schoenherr (2011), Berle et al. (2013) \\
\hline Metal & 3 & Hallikas et al. (2005), Wagner and Bode (2008), Kern et al. (2012) \\
\hline Retail & 3 & Tsai et al. (2008), Oke and Gopalakrishnan (2009), Le et al. (2013) \\
\hline Banking & 2 & Blome and Schoenherr (2011), Lundin (2012) \\
\hline Machinery & 2 & Wagner and Bode (2008), Kern et al. (2012) \\
\hline Insurance & 1 & Blome and Schoenherr (2011) \\
\hline Toy manufacturing & 1 & Tse and Tan (2011) \\
\hline
\end{tabular}




\section{University Library}

\section{- M M I E E R VA A gateway to Melbourne's research publications}

Minerva Access is the Institutional Repository of The University of Melbourne

Author/s:

Ho, W;Zheng, T;Yildiz, H;Talluri, S

Title:

Supply chain risk management: a literature review

Date:

2015

Citation:

Ho, W., Zheng, T., Yildiz, H. \& Talluri, S. (2015). Supply chain risk management: a literature review. International Journal of Production Research, 53 (16), pp.5031-5069. https:// doi.org/10.1080/00207543.2015.1030467.

Persistent Link:

http://hdl.handle.net/11343/118650 